\title{
REVIEW
}

\section{New drug delivery strategies targeting the GnRH receptor in breast and other cancers}

\author{
Hany Sadek Ayoub Ghaly ${ }^{1}$ and Pegah Varamini ${ }^{1,2}$ \\ 1School of Pharmacy (A15), The University of Sydney, Sydney, New South Wales, Australia \\ ${ }^{2}$ The University of Sydney Nano Institute, The University of Sydney, Sydney, New South Wales, Australia
}

Correspondence should be addressed to P Varamini: pegah.varamini@sydney.edu.au

\begin{abstract}
Cancer is the uncontrolled division of abnormal cells in a specific organ. Globally, about one in six deaths is due to cancer. Despite the plethora of research being undertaken worldwide to find a cure for cancer, it remains a significant challenge. Cancer targeting via agents designed to interfere with some specifically or highly expressed molecules in cancer cells has been a shift in the treatment of various forms of cancers. The development of drug delivery systems, specifically to cancer cells, is a common approach that succeeded in increasing the efficacy and reducing the side effects of different anticancer agents. Gonadotropin-releasing hormone $(\mathrm{GnRH})$ is a naturally occurring hormone with receptors overexpressed in many types of cancers related or unrelated to the reproductive system. Several drug delivery systems were developed using GnRH derivatives as targeting agents. In this review, we first discuss the role of GnRH and its receptors in cancer. Then, we provide a detailed insight into different delivery systems developed using GnRH derivatives as targeting agents in various types of GnRH receptor overexpressing cancers. Some promising findings from these studies indicate that GnRH receptor targeting is a potential strategy to efficiently guide anticancer therapeutics, diagnostic agents, and nucleic acids directly to cancer cells. Lastly, some limitations of the current research and suggestions for more successful outcomes in clinical trials of these delivery systems are highlighted.
\end{abstract}

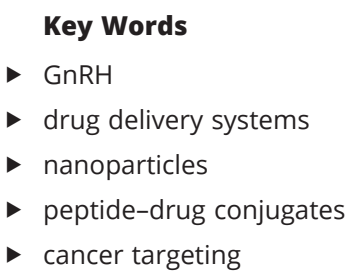

Endocrine-Related Cancer (2021) 28, R251-R269

\section{Introduction}

Cancer is a challenging health condition with a high mortality rate worldwide. According to the World Health Organization (WHO), cancer is the second leading cause of death. Low and medium-income countries are the most affected, with $70 \%$ of deaths occurring in these countries. An important reason behind the high mortality rate is the poor accessibility of therapeutic agents, especially chemotherapeutic agents, to cancer cells, in addition to their fast clearance from the blood and their destructive effects on healthy tissues due to non-selectivity
(Minko et al. 2013). These challenges might be addressed by targeting therapeutic agents exclusively to cancer cells via agents designed to interfere with some specifically or highly expressed molecules in cancer cells. This leads to an increase in the accumulation of therapeutic agents in cancer cells and so enhances their antitumor efficacy. On the other hand, using targeted delivery strategies reduce the side effects against healthy cells (Torchilin 2010).

Targeted therapeutics can be in the form of small molecules, peptide- or monoclonal antibody-conjugated 
drug delivery systems (DDSs), or nanotechnologybased DDSs. Tumor targeting can be via an active or passive approach. Active targeting uses a targeting molecule that will carry the therapeutic agent or the nanoformulation (loaded with a therapeutic agent) to the tumor microenvironment (TME) or directly to cancer cells overexpressing a receptor for the targeting molecule. Most approaches use a targeting agent that interacts with the receptor located at the surface of cancer cells, causing internalization of the whole DDS (Torchilin 2010, Bae \& Park 2011). Passive targeting depends on the accumulation of nano-size DDS, i.e., nanoparticles (usually between 100 and $200 \mathrm{~nm}$ ) in the TME (Tang et al. 2014). This higher accumulation is due to a phenomenon called enhanced permeability and retention effect (EPR), which is the easy escape of nanoparticles to TME through the leaky blood vessels in addition to their reduced clearance from TME by the impaired lymphatic drainage of the tumor (Bazak et al. 2014).

Metastasis is responsible for $90 \%$ of cancer-associated deaths (Wang et al. 2012). It can occur at any time: with the onset of diagnosis, during treatment, or even after recovery. Cancer metastasis is a complex process that includes many steps such as the escape of cancer cells from the primary tumor, invasion of the surrounding tissues, entering the circulation, the escape from the circulation to a secondary site, and the establishment of metastatic foci in the secondary site (He \& Shi 2014). Tumor targeting can be one of the most efficient ways to prevent metastasis by preventing the formation of metastatic foci or destructing those cells that contribute to the dissemination of tumors.

In this narrative review, we introduced gonadotropinreleasing hormone (GnRH) as a naturally occurring peptide hormone and its receptor with a pivotal role in human reproduction. Furthermore, we described the expression of $\mathrm{GnRH}$ receptor (GnRH-R) in different cancer types followed by a detailed review of different delivery systems developed using GnRH receptor ligands as targeting agents in cancer. In this section, we first discussed GnRH-targeted delivery systems using small platforms including GnRH-drug conjugates, GnRH-lytic peptide conjugates, and GnRH-imaging agent conjugates. In the second section, we provided an insight into the studies where nanotechnology-based platforms have been used, including polymeric drug delivery systems, dendrimers, micelles, lipid-based nanoformulations, inorganic systems, and nanogels. A schematic illustration of different delivery systems targeted with GnRH derivative is provided in Fig. 1.

(c) 2021 Society for Endocrinology Published by Bioscientifica Ltd. Printed in Great Britain

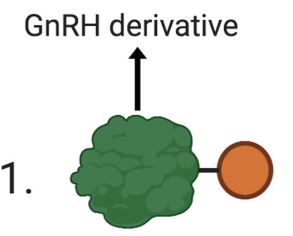

2.

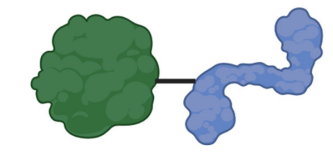

3.

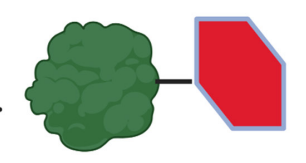

4.

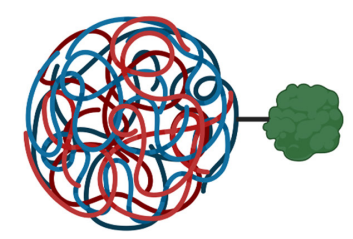

5.

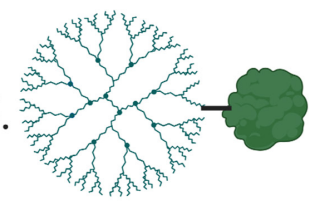

6.

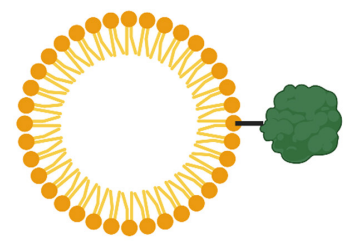

7.

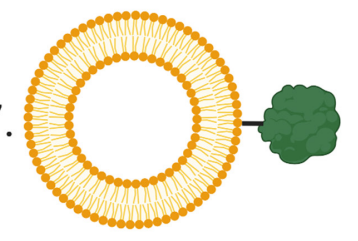

8.

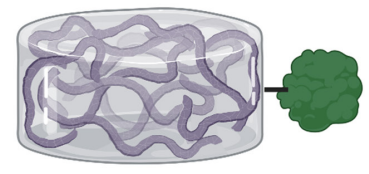

Figure 1

A schematic diagram of (1) PDC, GnRH derivative attached to a payload, (2) GnRH-lytic peptide conjugates, (3) GnRH-imaging agent conjugate, (4) a polymeric nanoparticle decorated with $\mathrm{GnRH},(5)$ a dendrimer attached to GnRH peptide, (6) a GnRH derivative-conjugated micelle, (7) a GnRH derivative-conjugated liposome, and (8) nanogel decorated with GnRH (Image created with BioRender.com).

\section{Gonadotropin-releasing hormone ( $\mathrm{GnRH})$ and GnRH receptor}

The hypothalamus produces GnRH in the form of decapeptide. It is also known as luteinizing hormonereleasing hormone (LHRH), gonadoliberin, luliberin, gonadorelin, and LHRH I. Although GnRH has several biological functions, it is extensively studied for its role in modulating the release of gonadotropins (luteinizing hormone or LH and follicle-stimulating hormone or FSH). GnRH binds specifically to the GnRH-R on the surface of gonadotropic cells in the anterior pituitary gland and stimulates the production and the release of gonadotropins in both adult men and women. In both men and women, LH stimulates the production of steroid hormones by the gonads (testes and ovaries), and FSH stimulates gamete production (Perrett \& McArdle 2013). There are over 20 isoforms of GnRH in vertebrae and protochordate species. Most vertebrates have at least two and most commonly three isoforms of GnRH, including GnRH I, GnRH II, and GnRH III (Table 1). These three isoforms have conserved 
Table 1 The peptide sequence of three GnRH isoforms.

\begin{tabular}{|c|c|}
\hline$\overline{\text { GnRH isoform }}$ & Sequence \\
\hline GnRH-I & pGlu-His-Trp-Ser-Tyr-Gly-Leu-Arg-Pro-Gly-NH2 \\
\hline GnRH-II & pGlu-His-Trp-Ser-His-Gly-Trp-Tyr-Pro-Gly-NH2 \\
\hline GnRH-III & pGlu-His-Trp-Ser-His-Asp-Trp-Lys-Pro-Gly-NH2 \\
\hline
\end{tabular}

C-terminal and N-terminal amino acid sequences, which play a pivotal role in binding to GnRH-R and activating it (Karten \& Rivier 1986, Kasten et al. 1996, Perrett \& McArdle 2013).

GnRH-R is a G-protein coupled receptor that activates the mitogen-activated protein kinase (MAPK) cascade leading to cell growth and proliferation. GnRH-R is overexpressed in cancers that are dependent on gonadal steroids such as prostate cancer $(86 \%$ of cases have overexpression of receptors with medium to high affinity to GnRH and its analogs), endometrial and ovarian adenocarcinomas (80\%), breast cancer (50\%), renal cancer (80\%), and pancreatic cancer (50\%) (Nagy \& Schally 2005, Gründker et al. 2011).

On a short arm of chromosome 8 (region 8p11.2, p21) exists the gene that encodes for GnRH peptide. The gene yields, upon expression, two peptides of 10 and 56 amino acid residues, and they are GnRH and GnRHassociated peptide (GAP), respectively (Yang-Feng et al. 1986). On chromosome 20 is the gene that encodes for GnRH II, which is $70 \%$ similar to GnRH, differing in only three amino acids (Table 1). GnRH II was found in the central nervous system, where it probably regulates sexual behavior. It was also found in the endometrium, ovary, and placenta, in addition to tumors derived from these tissues (Chen et al. 1998, Millar 2005).

GnRH-R is a membrane protein with seven hydrophobic transmembrane domains. It has a single amino acid chain with an extracellular amino-terminal domain and a cytoplasmic carboxyl-terminal domain. The activity of GnRH-R is affected by several factors. For example, the lack of the carboxyl-terminal tail and the unusual long cytoplasmic loop in GnRH-R cause slow desensitization and internalization of the receptor (Tsutsumi et al. 1992). The disruption of the disulfide bond between cysteine residues in GnRH-R decreases the receptor's affinity to GnRH (Fernald \& White 1999).

When GnRH binds to GnRH-R, the receptor undergoes conformational changes that indirectly activate phospholipase C (PLC). PLC converts membrane phosphoinositides to inositol 1,4,5-triphosphate (IP3). IP3 increases calcium influx into gonadotropic cells. Moreover, the activation of GnRH-R causes activation of calmodulin (a calcium channel messenger protein), which causes calcium influx as well. Calcium influx into gonadotropic cells causes the release of FSH and LH (Hislop et al. 2000). Besides, the activation of GnRH-R causes the activation of protein kinase $\mathrm{C}$ (PKC), which activates the MAPK cascades leading to an increase in the transcription of LH and FSH in gonadotropic cells (Harrison et al. 2004).

GnRH is released from the hypothalamus in a pulsatile manner. GnRH release's high frequency leads to LH secretion, while the low-frequency release causes FSH secretion (Thompson \& Kaiser 2014).

\section{GnRH receptors and cancer}

Several cancer tissues express receptors for GnRH such as prostate, endometrial, ovarian, and breast cancers (Halmos et al. 2000, Gründker et al. 2001). There are two types of GnRH-binding sites in cancer cells: (1) high affinity with low capacity sites (fully act at low GnRH concentration), and (2) low affinity with high capacity sites (act only at high concentration of GnRH). The high-affinity sites are similar to GnRH-R found in pituitary gonadotropic cells (Grundker et al. 2002). The low-affinity binding site is similar to the GnRH-R in the human placenta and corpus luteum (Eidne et al. 1987). The high-affinity binding sites were found in specimens of some cancers, including $86 \%$ of prostate cancer, $80 \%$ of human endometrial and ovarian cancers, $80 \%$ of renal cancer, and $32-50 \%$ of pancreatic cancers (Imai et al. 1994, Nagy \& Schally 2005, Gründker et al. 2011) as well as 50-64\% of breast cancers (Fekete et al. 1989) including 74\% of triple-negative breast cancers (TNBCs) (Fost et al. 2011). Although GnRH II isoform seems to be non-functional in humans (Gründker et al. 2002a), it was found in cancers of human reproductive organs (Eicke et al. 2005).

GnRH agonists were found to cause time- and dosedependent reduction in the proliferation of human endometrial, ovarian, breast, and prostate cancer cell lines (Grundker et al. 2002, Emons et al. 2003). Surprisingly, GnRH antagonists were found to have the same effect as GnRH agonists. These findings indicated that their direct antiproliferative effect in cancer is not differentiated from GnRH agonists (Grundker et al. 2002, Emons et al. 2003). In a pancreatic cancer cell line, it was shown that GnRH overexpression significantly inhibited cell proliferation. In addition, these results indicated that the increasing $\mathrm{GnRH}$ expression significantly induced downregulation of $B C L 2$ expression and upregulation of $B A X, C-M Y C$, cleaved caspase-3, and cleaved caspase-9 in Panc1 cell groups, which indicated that GnRH might induce apoptosis in 
pancreatic cancer. Inhibition of GnRH also led to higher invasiveness in Panc1 cells (Suo et al. 2019).

GnRH analogs were found to inhibit metastasis of MCF-7 and MDA-MB-231 breast cancer cell lines (von Alten et al. 2006) in addition to prostate cancer cell lines DU145 and PC3 (Dondi et al. 2006). The reduction of invasiveness by GnRH analogs may be due to inhibiting the expression of S100A4 and CYR61 genes, which play an important role in cancer cell metastasis (Gründker et al. 2016). An increased CYR61 level correlates with a poor prognosis, poor lymph node status, and metastatic propagation. Transfected breast cancer cells for S100A4 overexpression were shown to be markedly more invasive than the nontransfected controls (Gründker \& Emons 2017).

GnRH agonists mainly counteract the signaling of growth factor receptors through activation of protein tyrosine phosphatase (PTP), which decreases the phosphorylation of EGF receptor, leading to a reduction in cancer cells proliferation (Emons et al. 1998). On the other side, GnRH antagonists mainly induce apoptosis via stimulation of pro-apoptotic factor Bax, loss of mitochondrial membrane potential, cytochrome $\mathrm{C}$ release, and caspase-3 activation (Fister et al. 2007).

Due to poor metabolic stability, GnRH analogs require parenteral administration (Khazeni \& Varamini 2018). Their conventional clinical applications largely involve their use as androgen deprivation therapy for the treatment of advanced hormone-dependent cancers, including prostate cancer. They are used off-label for precocious puberty, gender dysphoria, and infertility (Kumar \& Sharma 2014).

\section{Targeted therapy using GnRH derivatives}

Although GnRH-R is expressed in the healthy tissues of reproductive organs, pituitary gland, and to a significantly greater extent in certain types of cancer, it is not expressed in most of the healthy tissues and hematopoietic stem cells. This overexpression pattern makes it an attractive target for DDS to deliver therapeutic agents exclusively to tumor cells and hence, reduce the side effects and increase the efficacy of these agents (Schally \& Nagy 1999). Although GnRH-R is expressed in the pituitary gland, one study showed that GnRH-targeted DDS was not able to escape through the barriers that separate the pituitary gland and the systemic circulation. This led to GnRH-R-targeted DDSs having no adverse effect on the normal function of the pituitary gland (Dharap et al. 2005). The LH level in mice blood treated with GnRH-targeted DDS was measured, and it was shown to be within the normal range. Furthermore, female mice treated with GnRH-targeted DDS gave healthy offsprings (Dharap et al. 2005).

In clinical trials, AEZS-108 (GnRH linked to doxorubicin (DOX)) caused no permanent impairment of the pituitary gland function (Emons et al. 2010).

\section{GnRH-targeted delivery systems: small platforms}

\section{GnRH-cytotoxic drug conjugates}

Peptide-drug conjugates (PDCs) are among the important targeted delivery systems that incorporate drug molecule(s) linked to a peptide directly through a covalent bond or indirectly via a biodegradable linker (Fig. 1.1). A famous example of PDCs incorporating GnRH is the cytotoxic GnRH analog or GnRH-drug conjugate in which GnRH or one of its derivatives is covalently bound to a cytotoxic agent.

The GnRH analog carries the PDC to the surface of cancer cells overexpressing GnRH-R where it interacts with the receptor leading to the internalization of the whole PDC. Inside the cancer cells and mainly in endosomes, the covalent bond is broken, releasing the free cytotoxic agent (Schally \& Nagy 1999). These steps are represented in Fig. 2. In most GnRH-based DDSs, glycine in position 6 of GnRH is replaced by D-Lys, which makes the peptide more resistant to biodegradation, improves binding affinity to GnRH-R, and leaves a reactive amino functional group at position 6 (Li et al. 2017).

Nagy et al. designed a PDC in which DOX was conjugated to a GnRH analog, [D-Lys 6 ] GnRH via a glutaryl spacer (Nagy et al. 1996). This PDC (zoptarelin DOX, AEZS-108, or AN-152, Fig. 3) was successful in the targeted delivery of DOX to GnRH-R-positive cancer cell lines of breast, ovary, and endometrium. In in vitro studies, the PDC was not significantly uptaken by cancer cell lines without GnRH-R overexpression. In vitro studies showed that AN-152 was more potent than DOX in inhibiting the growth of GnRH-R overexpressing cancer cell lines. In vivo studies also showed that $\mathrm{AN}-152$, in comparison to free DOX, is more potent in tumor-bearing mice and less toxic to healthy tissues (Gründker et al. 2002b, Engel et al. 2007).

Surprisingly, AN-152 (AEZS-108) showed cytotoxic activity against GnRH-R-negative cell lines (Nagy et al. 2000). This might have been due to the release of free DOX from the PDC in the blood by enzymatic cleavage or hydrolysis which reflects the poor metabolic stability of AN-152 in the blood circulation. In one in vitro study, it was found that serum carboxylesterase enzymes can hydrolyze AN-152 and release free DOX into the blood before the PDC was uptaken by cancer cells (Nagy et al. 2000). The higher
(C) 2021 Society for Endocrinology Published by Bioscientifica Ltd. Printed in Great Britain 


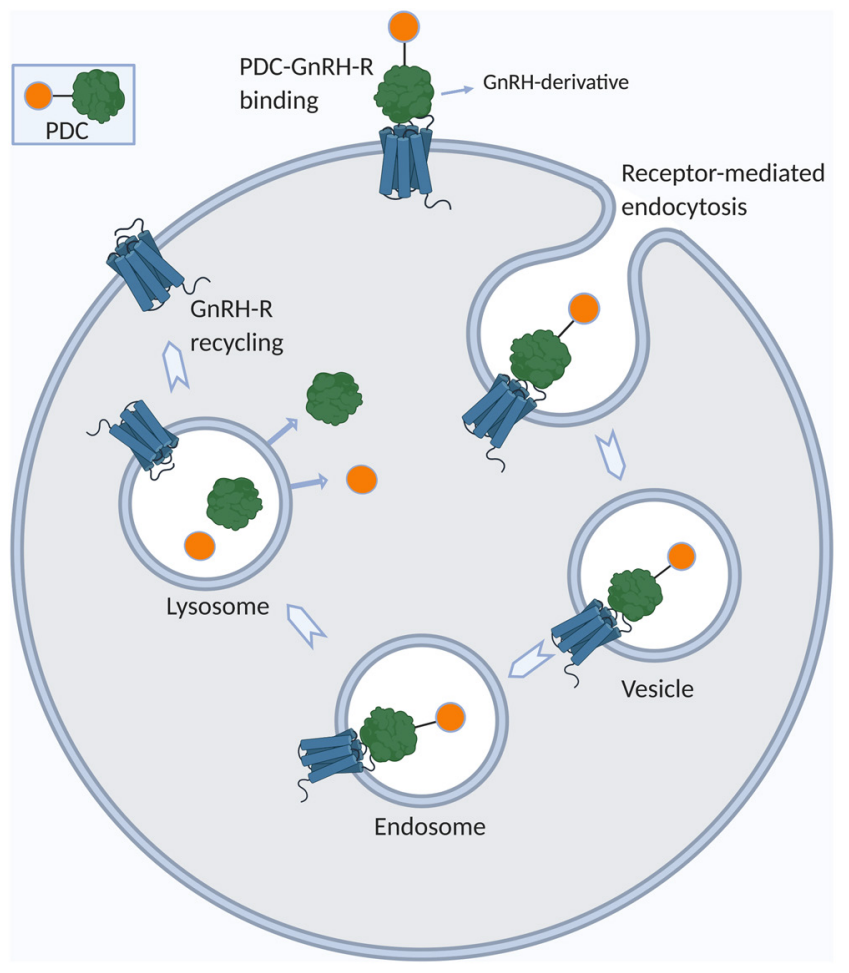

Figure 2

A schematic representation of GnRH-R-mediated endocytosis of PDCs. A similar mechanism is involved in the internalization of all other GnRH-Rtargeted DDSs in cancer cells (Image created with BioRender.com).

the activity of the serum carboxylesterase enzyme, the shorter the half-life of the PDC. For example, nude mice have enzymes that are ten times more active than those in humans, and that is the reason why the half-life of AN-152 was $120 \mathrm{~min}$ in humans compared to only $10 \mathrm{~min}$ in nude mice. To further examine this hypothesis, diisopropyl fluorophosphate was added to mice serum to inhibit the carboxylesterase enzymes and this prolonged the half-life of AN-152 to 70 min which resulted in better targeting of cancer cells (Nagy et al. 2000).

Despite preclinical studies showing low stability of AN-152, this PDC reached clinical trials. In phase II trials, it proved to be effective and of low toxicity in women with GnRH-R-positive endometrial cancer. Five percent of 44 patients enrolled in that trial achieved complete remission, $19 \%$ had partial remission, $47 \%$ had stable disease, and 21\% had progressive disease (Emons et al. 2014b). In another phase II trial on women with resistant ovarian cancers, AN-152 showed to be safe and effective (Emons et al. 2014a). AN-152 was granted orphan drug status for endometrial and ovarian cancers by the US FDA (Li et al. 2017). In phase III clinical trials, AN-152 did not improve overall survival, progression-free survival, overall response

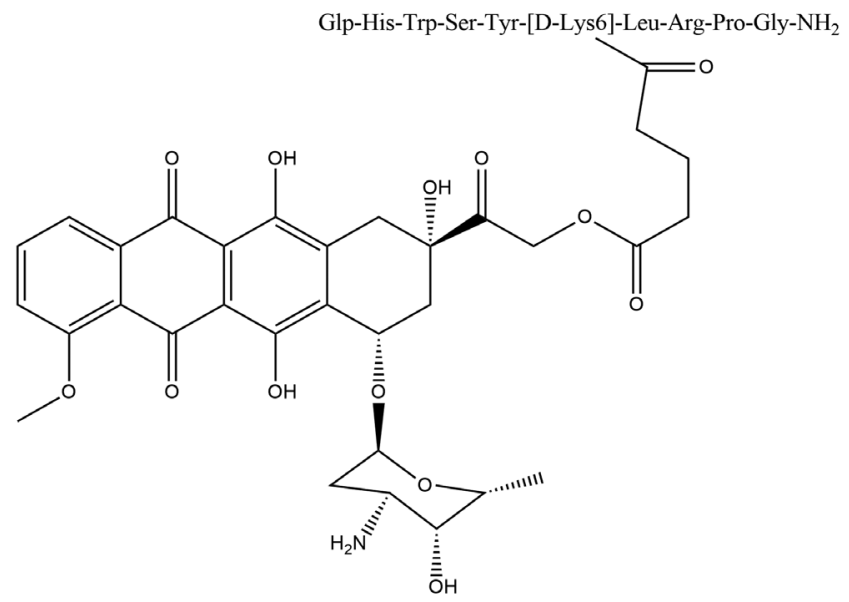

AN-152

\section{Figure 3}

The chemical structure of AN-152 (AEZS-108). The 14-OH group of DOX was conjugated to the $\varepsilon-\mathrm{NH}_{2}$ of [D-Lys 6 in $\left[D-\right.$ Lys $\left.^{6}\right] \mathrm{GnRH}$ through a glutaric acid spacer.

rate, clinical benefit rate, or adverse events compared to free DOX as second-line therapy for advanced endometrial cancers (Miller et al. 2018).

While DOX was used in AN-152, 2-pyrroline DOX, which is a DOX derivative with 500-1000 times higher potency was used in AN-207 (Fig. 4). In nude mice with ovarian cancer xenografts overexpressing GnRH-R, AN-207 significantly inhibited tumor growth while 2-pyrroline DOX did not affect tumor growth and it was also toxic to animals (Miyazaki et al. 1999). One study showed that AN-207 caused rats to lose $15 \%$ of body weight and decreased the release of LH from the pituitary gland by $63 \%$, but the later effect was reversible (Kovacs et al. 1997).

GnRH-R was recently reported to be overexpressed in $46 \%$ of uveal melanoma. A study examined the cytotoxic effect of AEZS-108 on OCM3 uveal melanoma cells. Results showed that AEZS-108 and DOX reduced cell proliferation by $36.3 \%$ and $62.9 \%$, respectively, after $24 \mathrm{~h}$, and by $84.7 \%$ and $89.7 \%$, respectively, after $48 \mathrm{~h}$. AEZS-108 was found to alter the expression of numerous genes in uveal melanoma (Fodor et al. 2020).

Obayemi et al. conjugated D-Lys ${ }^{6}$-modified GnRH with prodigiosin (PGS) and paclitaxel (PTX) for the treatment of TNBC. The GnRH derivative delivered both drugs to TNBC cells in in vitro studies. While both PDCs showed stronger antitumor activities than free PTX and PGS in TNBC models, GnRH-conjugated PGS was more potent than GnRH-conjugated PTX in MDA-MB-231 cells. Mice treated with conjugates had healthy primary organs with no observable physiological changes (Obayemi et al. 2020). (c) 2021 Society for Endocrinology Published by Bioscientifica Ltd. Printed in Great Britain 
Glp-His-Trp-Ser-Tyr-[D-Lys6]-Leu-Arg-Pro-Gly- $\mathrm{NH}_{2}$

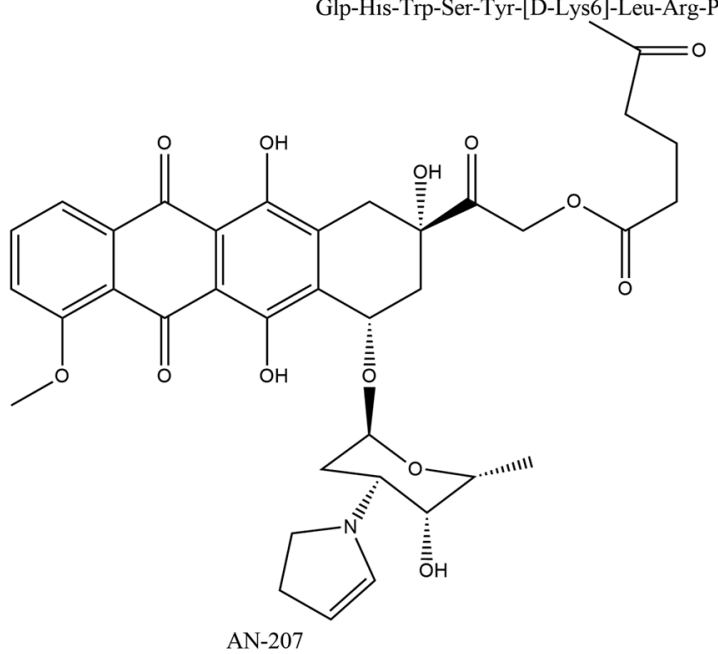

Figure 4

The chemical structure of AN-207. Through a glutaric acid spacer, the 14-OH group of 2-pyrrolinoDOX was conjugated to the $\varepsilon-\mathrm{NH}_{2}$ of [D-Lys 6 ] in [D-Lys $\left.{ }^{6}\right] \mathrm{GnRH}$ analog.

In another study, GnRH was conjugated to PGS or PTX to yield a PDC, which was then encapsulated in poly lacticco-glycolic acid-PEG (PLGA-PEG) polymer microspheres. Both PDCs exerted stronger growth inhibition activities in MDA-MB-231 cells compared to free drugs. No toxicity was observed in mice. In addition, both free drug-loaded and PDC-loaded microspheres significantly prolonged the survival of mice compared to untreated mice $(P<0.0001)$. Treatment with PDC- loaded microspheres resulted in a higher prolongation of mice survival compared to microspheres loaded with free drugs (Jusu et al. 2020).

Curcumin was another agent to be conjugated to [D-Lys ${ }^{6}$-GnRH (Fig. 5) and studied for the treatment of pancreatic cancer. The curcumin-GnRH conjugate was as effective as free curcumin when tested on three different pancreatic cancer cell lines. In MIAPaCa-2 cancer cell xenografts in athymic mice, the curcumin-GnRH conjugate effectively prevented the tumor growth as there was no change in the tumor weight before and after treatment with the conjugate (Aggarwal et al. 2011).

Crizotinib is an effective multi-target kinase inhibitor which is approved against anaplastic lymphoma kinase (ALK) or ROS proto-oncogene 1 (ROS1)-positive non-small cell lung carcinoma (NSCLC). A research group developed novel crizotinib analogs and conjugated them to [D-Lys ${ }^{6}$ GnRH derivative. In the EBC-1 NSCLC cell line, the novel analog MJ55* was equally effective as crizotinib $\left(\mathrm{IC}_{50}=23\right.$ $\mathrm{nM}$ ) and the $\mathrm{IC}_{50}$ of $\mathrm{GnRH}-\mathrm{MJ} 55^{*}$ was $90 \mathrm{nM}$ in comparison to no significant cytotoxic effect of GnRH-crizotinib (Murányi et al. 2019).

Deslorelin is a GnRH superagonist which was conjugated to docetaxel (DTX) to yield a conjugate that has stronger antitumor activity against a lung cancer cell line compared to free DTX. In the same study, a combination of deslorelin-DTX conjugate and RGD peptide-conjugated nanoparticles encapsulating an anti-vascular endothelial growth factor (VEGF) intraceptor (Flt23k) was administered to mice. Results showed that the combination therapy was more effective than individual agents or free DTX in inhibiting tumor growth and angiogenesis DTX (Sundaram et al. 2009).

GnRH-III is an isoform of GnRH (sea lamprey analog), which possesses an insignificant effect on the pituitary gland but strong binding to GnRH-R on cancer cells. GnRH-III was conjugated to daunorubicin via an oxime bond and the conjugate showed significant cytotoxicity to cancer cells (Szabó et al. 2009, Orbán et al. 2011).

In another report, 14 oxime bond-linked daunorubicinGnRH-III conjugates were synthesized. All conjugates exhibited cytotoxic activity in a dose-dependent manner on MCF-7 (breast) as well as on HT-29 (colon) human cancer cells. One conjugate (GnRH-III-[ $\left[\mathrm{His}^{2}, \mathrm{D}-\mathrm{Tic}^{3}\right.$,Lys $(\mathrm{Bu})^{4}$,Lys $\left.(\mathrm{Dau}=\mathrm{Aoa})^{8}\right]$ ) showed the highest stability in human plasma, had a high binding affinity for the GnRHreceptor, and was able to specifically target the payload to the cancer cells (Schuster et al. 2018). In an in vivo study

\section{GnRH-curcumin}

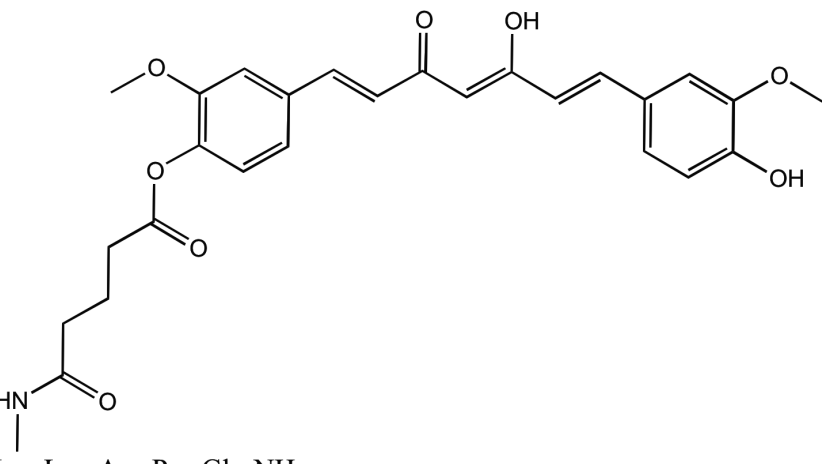

Glu-His-Trp-Ser-Tyr-D-Lys-Leu-Arg-Pro-Gly-NH $\mathrm{NH}_{2}$

Figure 5

The structure of a curcumin-based PDC conjugated to $\mathrm{GnRH}$. 
on colorectal and breast cancer-bearing mice, GnRH-III$\left[\Delta \mathrm{His}^{2}, \mathrm{D}-\mathrm{Tic}^{3}, \mathrm{Lys}(\mathrm{Bu})^{4}, \mathrm{Lys}(\mathrm{Dau}=\mathrm{Aoa})^{8}\right]$ conjugate decreased the proliferation index by $25.9 \%$ while free daunorubicin decreased this index by 19\% (Ranđelović et al. 2019).

In addition to cytotoxic agents, GnRH analogs were also conjugated to the two phototsensitizers, protoporphyrin IX and zinc phthalocyanine (Pc) in two different studies. The two studies showed that GnRH analogs enhanced the internalization of the photosensitizers into GnRH-Rpositive cancer cell lines with no negative impact on the ability of photosensitizers to generate reactive oxygen species (ROS) (Rahimipour et al. 2003, Xu et al. 2012).

In a different study, protoporphyrin IX was conjugated to a butyric acid-modified GnRH analog, $\left[\mathrm{Lys}^{4}(\mathrm{Bu})\right] \mathrm{GnRH}$, to yield a conjugate with enhanced metabolic stability. In a head and neck squamous cell carcinoma (HNSCC) cell line (Detroit-562), all GnRH-protoporphyrin IX conjugates were more active than free protoporphyrin IX (Pethố et al. 2019).

\section{GnRH-lytic peptide conjugates}

Lytic peptides can be found in nearly all multi-cellular and some single-cellular living organisms. They generally consist of 10-40 amino acids, which have the potential to form discrete secondary structures (Yates et al. 2011). GnRH has been used to deliver different lytic peptides to cancer cells with the aim of causing direct lysis of cancer cells. Figure 1.2 shows an illustration of GnRH-lytic peptide conjugates.

Deng et al. conjugated B1 peptide (an anticancer peptide) to GnRH, triptorelin, and another derivative. Results showed that all peptide conjugates were cytotoxic to GnRH-overexpressing cell lines, especially DU145 and SMMC-7721. Triptorelin-B1 conjugate (TB1) showed the highest plasma stability in comparison to other conjugates. TB1 was shown to have a pro-apoptotic and an antimigratory effect on the DU145 cells (Deng et al. 2015).

EP-100 is an oncolytic peptide consisting of [D-Lys 6 ] GnRH ligand directly linked to a lytic peptide called CLIP71. With the screening of 18 cancer cell lines, EP-100 was found to be effective against GnRH-R-positive cancer cells, including multidrug-resistant cell lines. EP-100 showed minimal activity against GnRH-R-negative cancer cell lines. In GnRH-R-positive cancer cells, EP-100 was more active than CLIP71 by 28.5 -fold after $24 \mathrm{~h}$. In ovarian cancer xenograft models, EP-100 caused a significant decrease in the tumor weight compared to CLIP71, or cisplatin (Leuschner 2017). In addition to its direct oncolytic property, EP-100 was found to increase the levels of programmed death-ligand 1 (PD-L1) mRNA and protein in ID8 and IG10 ovarian cancer cells. EP-100 was combined with an antibody against PD-L1, and the combination showed greater tumor growth inhibition in vivo (82.7\%) in comparison to EP-100 (60.1\%) or the antibody (60.1\%). Moreover, EP-100 can cause tumor lysis indirectly by promoting some TME factors such as CD8+ T cells, NK cells, dendritic cells, and macrophages. On the other hand, the conjugate could suppress immune-inhibitory cells. Furthermore, EP-100 increased the secretion of various molecules, including IL33, known for inhibiting tumor growth and modifying the tumor microenvironment (Kim et al. 2020). The use of EP-100 progressed to clinical trials where in a phase I clinical trial, EP-100 did not cause any grade 3 or 4 adverse events in patients. A stable disease for 16 weeks was found in 19\% of patients with pancreatic, ovarian, breast, or endometrial cancers (Curtis et al. 2014). In a phase II clinical trial, EP-100 appeared to sensitize PTXresistant ovarian tumors leading to further shrinkage of target and non-target lesions and prolongation of response (Nick et al. 2015).

In one study, a GnRH analog was conjugated to two different lytic peptides, namely JCH and JC21, yielding JCHGnRH and JC21GnRH conjugates, respectively. These conjugates showed an antiproliferative activity in the micromolar range in different prostate cancer cell lines. Furthermore, the GnRH derivative itself caused some antiproliferative activity in these cells, yet the highest dose did not reach $50 \%$. Depletion of GnRH-R in cancer cells by siRNA decreased the sensitivity of cells to both conjugates by $50 \%$ (Yates et al. 2011).

Pseudomonas aeruginosa exotoxin 40 (PE40) was conjugated to GnRH to yield GnRH-PE40 conjugate. GnRH-PE40 showed improved cytotoxicity in cells expressing higher GnRH-R levels (Deng et al. 2008).

One study examined the effect of the lytic peptide Hecate and its conjugates, GnRH-Hecate and Hecate$\beta C G$ (Hecate conjugated to a 15 amino acid segment of $\beta$ chain of chorionic gonadotropin hormone) against two breast cancer cell lines, MCF-7 and MDA-MB-435S. In both cell lines, $\mathrm{EC}_{50}$ values were within the micromolar range. It was noted in this study that the MCF-7 cell line lost its sensitivity to both lytic conjugates when steroids were removed from the medium (Leuschner et al. 2003) indicating the role of steroids in the antitumor effects of the conjugates. The role of steroids in the direct antiproliferative activity of GnRH analogs was also confirmed in some other studies (Goodwin et al. 2015, Varamini et al. 2017). (c) 2021 Society for Endocrinology Published by Bioscientifica Ltd. Printed in Great Britain 


\section{GnRH-imaging agent conjugates for diagnostic applications}

GnRH has been used in conjugation with imaging agents (Fig. 1.3) such as radionucleotides to specifically deliver them to cancer cells for cancer imaging by positron emission tomography (PET) or single-photon emission computed tomography (SPECT).

Guo et al. conjugated $\left[\mathrm{D}-\mathrm{Lys}^{6}(\mathrm{Ahx})\right] \mathrm{GnRH}$ to a chelating agent called 1,4,7,10-tetraazacyclododecane1,4,7,10-tetraacetic acid (DOTA) and used this conjugate to deliver ${ }^{111} \mathrm{In}$ to breast and prostate cancer cells. The conjugate showed rapid accumulation in the two types of cancer, specific binding to GnRH receptor and efficient visualization of cancer tissues by SPECT (Guo et al. 2011a,b).

Ferrosoferric oxide $\left(\mathrm{Fe}_{3} \mathrm{O}_{4}\right)$ nanoparticles were conjugated to GnRH for imaging of breast cancer using chitosans. Targeted nanoparticles delivered significantly more iron particles to MCF-7 cells than non-targeted nanoparticles. Targeted nanoparticles showed timedependent accumulation in tumor tissues in animals under magnetic field (Nian et al. 2019).

$\mathrm{Hu}$ et al. examined the effectiveness of magnetite nanoparticles (MNPs) and GnRH-MNPs as MRI contrast agents for the specific imaging of TNBC. In vitro studies showed that both nanoparticles could effectively serve as $\mathrm{T}_{2}$-based contrast agents. Compared to MNPs, intratumoral injection of GnRH-MNPs resulted in an overall higher relative contrast that was preserved at $\sim 60 \%$ over a period of 2 weeks. In contrast to MNPs, the i.v. injection of GnRHMNPs resulted in a significant signal attenuation in the tumor region (Hu et al. 2020).

\section{GnRH-targeted delivery systems: nanotechnology-based platforms}

The conjugation of GnRH or its analogs to the surface of nanoparticles is another common strategy to target therapeutics to cancer cells. These platforms have shown an enhanced uptake by GnRH-R-positive cancer cells and reduced accumulation in normal tissues in addition to an improved aqueous solubility of the whole DDS. GnRH analogs were also shown to enhance the stability, reduce the uptake by the reticuloendothelial system (RES), and increase the circulation time of the whole DDS (Li et al. 2017). Several studies that investigated the development of different nanoparticles loaded with an anticancer therapeutic and decorated with GnRH or its analogs on the surface for targeting purposes are summarised in the below section.

\section{Polymeric nanoparticles}

Polymeric nanoparticles are solid colloidal particles made from natural or synthetic polymers with a size range of 1-1000 nm. Polymeric nanoparticles have been successfully used as carriers for different diagnostic and therapeutic agents (Bolhassani et al. 2014). Figure 1.4 exemplifies a GnRH-conjugated polymeric nanoparticle.

Polyethylene glycol (PEG) was conjugated to a GnRH analog (Gln-His-Trp-Ser-Tyr-D-Lys(D-Cys)-Leu-Arg-ProNHEt, $\left.\left[\mathrm{Q}^{1}\right]\left[\mathrm{k}^{6}\left(\mathrm{c}^{6}\right)\right]\left[\mathrm{P}^{9}-\mathrm{NEt}\right] \mathrm{GnRH}\right)$ on one end and a plantderived topoisomerase I inhibitor (camptothecin or CPT) on the other end and then formulated into nanoparticles. In comparison to free CPT and PEG-CPT nanoparticles, the GnRH-PEG-CPT nanoparticles had higher cytotoxicity to human ovarian cancer cell lines (Dharap et al. 2003). In in vivo studies, the GnRH-PEG-CPT nanoparticles significantly reduced the tumor size of human ovarian cancer xenograft in mice in comparison to free CPT and PEG-CPT nanoparticles $(P<0.05)$. The reason for the higher cytotoxic activity of GnRH-PEG-CPT nanoparticles, as the study demonstrated, was that attaching the $\mathrm{GnRH}$ analog to PEG-CPT conjugates increased the accumulation in tumor cells by two-fold (Dharap et al. 2005).

Khandare et al. used a multivalent spacer (citric acid) to attach more than one molecule of a GnRH analog and an anticancer drug to bis(2-carboxyethyl)-PEG and formulate nanoparticles. Both in vitro and in vivo studies showed that the anticancer effect of the DDS increased as the number of the attached GnRH analog and anticancer drug increased and up to three copies of GnRH and the anticancer drug (Khandare et al. 2006).

In a similar study, citric acid was used as a linker to attach several copies of GnRH, CPT, B-cell lymphoma 2 (BCL2) peptide, and homolog 3 domain (BH3) peptide to PEG. The resultant nanoparticles caused a stronger apoptotic response in human ovarian cancer cell lines in comparison to free CPT and PEG-CPT conjugate. Several treatments of mice bearing human ovarian xenografts with the formulated nanoparticles caused nearly complete regression of the primary tumor (Chandna et al. 2010).

The Minko group studied the effect of attaching a GnRH analog to three different nanoparticles on their antitumor activities. The different nanocarriers included linear polymer PEG nanoparticles, fourth-generation polyamidoamine (PAMAM) dendrimers, and PEGylated liposomes and they were all loaded with PTX as the anticancer agent. Results showed that conjugation of GnRH analogs to the nanoparticles significantly increased their antitumor activity. In addition, it reduced nanoparticle accumulation in healthy tissues resulting in a significant 
reduction of PTX adverse effects. These findings suggested that active targeting by GnRH analogs minimized the difference in anticancer activity and side effects between DDSs with different architecture, size, molecular mass, and composition (Saad et al. 2008, Li et al. 2015).

Methotrexate-human serum albumin (MTX-HSA) nanoparticles were conjugated to high, medium or low numbers of GnRH molecules. GnRH succeeded in significantly improving the uptake of the conjugate by breast cancer cells in addition to improving its anticancer activity. The larger the number of GnRH molecules attached to the nanoparticles, the higher cytotoxicity of nanoparticles in breast cancer cells (Taheri et al. 2011).

PLGA was used to formulate nanoparticles loaded with PTX and decorated with [D-Lys 6 GnRH via a PEG linker. The targeted nanoparticles were significantly less hemolytic than free PTX and non-targeted nanoparticles (4.12\% in comparison to $30.12 \%$ and $5.81 \%$, respectively). The $\mathrm{IC}_{50}$ for the targeted nanoparticles was five times lower than non-targeted ones and two times lower than free PTX in GnRH-R overexpressing MCF-7 cells. In MCF-7 tumorbearing mice, targeted nanoparticles prolonged the blood circulation of PTX, lowered the uptake by healthy tissues, and increased the uptake by the tumor tissue by 4.4 -fold in comparison to free PTX. The average fractional tumor volumes were 8.3 for PTX and 2.2 for targeted nanoparticles 3 weeks after treatment (Ghanghoria et al. 2016).

In another study, DOX and quercetin were encapsulated in [D-Lys 6 GnRH-PEG- PLGA nanocapsules. Nanocapsules showed higher uptake and anticancer effects with increased caspase-3 activity in PC-3 and LNCaP cell lines in comparison to free drugs. In in vivo studies, targeted nanocapsules accumulated more in tumor sites than the free drugs. In vivo studies also showed enhanced antitumoral activity of targeted nanocapsules loaded with both drugs in comparison to free drugs or targeted nanocapsules bearing a single drug only (Shitole et al. 2020).

Varshosaz et al. developed dual-targeted micelles in which DOX was co-loaded with iron-zinc in the core. Micelles were first coated by a negatively charged polymer such as acacia and then with GnRH-conjugated poly(methyl vinyl ether maleic acid)/chitosan copolymer. The GnRH molecule and an external magnetic field internalized the nanoparticles into cancer cells. In the absence or presence of the magnetic field, targeted nanoparticles were significantly more capable of inhibiting MCF-7 cell viability in comparison to non-targeted nanoparticles and free DOX (Varshosaz et al. 2016).

\section{Dendrimeric platforms}

Dendrimers are nanosized 3D multivalent architectures comprised of three different domains known as the core, the branching layer, and the corona at the outer periphery. Multifunctional dendritic polymers have been long investigated for application as gene delivery systems with low toxicity and significant transfection efficiency (Kesharwani et al. 2014). An illustration of a dendrimeric nanoparticle attached to GnRH is shown in Fig. 1.5.

PEGylated poly(propylene imine) (PPI) dendrimers were used to deliver $C D 44$ siRNA. The dendrimer was caged with a dithiol crosslinker to improve stability and coated with PEG linked to a GnRH derivative $\left(\left[\mathrm{Q}^{1}\right]\left[\mathrm{k}^{6}\left(\mathrm{c}^{6}\right)\right]\left[\mathrm{P}^{9}-\mathrm{NEt}\right]\right.$ $\mathrm{GnRH})$ at the distal end for targeting purposes. The DDS was stable in plasma, exclusively accumulated in GnRHR-positive A549 lung tumor cells, and efficiently silenced the targeted gene (Taratula et al. 2009). Those dendrimers were then used to deliver PTX via a pH-sensitive linker. This targeted DDS successfully silenced the CD44 gene and decreased the tumor resistance to PTX leading to almost complete tumor eradication in animals (Shah et al. 2013, Schumann et al. 2015).

A PAMAM-based dendrimer was designed with positively charged internal cavities to enhance siRNA complexation efficiency and neutral external surface to reduce toxicity. The GnRH-conjugated dendrimer significantly silenced the target gene in GnRH-R-positive ovarian cancer cells (Patil et al. 2009, Minko et al. 2010).

Photothermal therapy (PTT) is a cancer treatment approach that induces cancer cell death by using absorbents that generate heat in tumor tissues when exposed to nearinfrared (NIR) light (Nomura et al. 2020). Photodynamic therapy (PDT) is based on a photochemical reaction between a light activatable molecule or photosensitizer, light, and molecular oxygen. The reaction produces ROS which can directly damage cells or vasculature and induce inflammatory and immune responses (van Straten et al. 2017).

GnRH-conjugated PPI dendrimers were used to complex with Pc for PDT properties and then with lowoxygen graphene nanosheets to add PTT characteristics. Low-power near-infrared irradiation was used to generate heat from graphene nanosheets and ROS from Pc. This combination therapy killed $90-95 \%$ of ovarian cancer cells (Taratula et al. 2015).

The Minko group developed a complex DDS in which superparamagnetic iron oxide nanoparticles (SPIONs) were used with poly(propylene imine) generation 5 dendrimers (PPIG5) to cooperatively form nanoparticles in which a siRNA against BCL2 was complexed. The surface 
of the DDS was modified by PEG to increase steric stability. A GnRH analog $\left(\left[\mathrm{Q}^{1}\right]\left[\mathrm{k}^{6}\left(\mathrm{C}^{6}\right)\right]\left[\mathrm{P}^{9}-\mathrm{NEt}\right] \mathrm{GnRH}\right)$ was coupled to the distal end of PEG which significantly increased the uptake of the DDS by GnRH-R-overexpressing cell line, A549 (Taratula et al. 2011b).

\section{Micelles}

Micelles are colloidal particles with a diameter of 5-100 $\mathrm{nm}$ made from the assembly of surfactants (Fig. 1.6). Surfactants are molecules with a polar head (which may be cationic, anionic, zwitterionic, or non-ionic) and nonpolar alkyl tail (Hanafy et al. 2018).

Amphiphilic block copolymers are commonly used for the fabrication of polymeric micelles. Jing et al. synthesized a triblock copolymer consisting of poly(ethylene oxide)block-poly(allyl glycidyl ether)-block-poly(DL-lactide) (mPEG-b-PAGE-b-PLA) and conjugated it to a GnRH analog $\left(\left[\mathrm{Q}^{1}\right]\left[\mathrm{k}^{6}\right] \mathrm{GnRH}\right)$. The conjugate self-assembled into micelles that were loaded with DOX. Micellesshowed a higher uptake in GnRH-R-positive HeLa cells than cells lacking GnRH-R. In HeLa cell-injected animal models of mice, the micelles were shown to accumulate more in tumor cells (Wang et al. 2013).

PEG-b-poly(carbonate-co-lactide) copolymer was used to form micelles loaded with an antiandrogen (CBDIV17) and decorated with $\mathrm{GnRH}$ peptide $\left(\left[\mathrm{k}^{6}\right] \mathrm{GnRH}\right)$ for prostate cancer targeted therapy. These micelles were preferentially uptaken by cancer cells showing higher cytotoxicity and growth inhibition in vitro and in vivo (Wen et al. 2014).

$\mathrm{Wu}$ and co-workers constructed $\mathrm{pH}$-sensitive micelles using GnRH-modified poly(ethylene glycol)-poly(Lhistidine). Micelles were loaded with DOX-human immunodeficiency virus (HIV) trans-acting transcriptional activator (TAT) protein (DOX-TAT) conjugate. The micelles accumulated in the TME where some micelles dissociated at the acidic $\mathrm{pH}$ of the TME releasing the DOX-TAT conjugate, which was uptaken by cancer cells via the TAT-mediated pathway. Undissociated micelles at TME pH were uptaken by cancer cells via GnRH-mediated endocytosis. At TME $\mathrm{pH}$ (6.8), DOX-TAT-loaded micelles were more cytotoxic to A2780/Dox ${ }^{\mathrm{R}}$ cells (25\% viability) in comparison to DOXmicelles and free DOX (74\% vs 93\% viability, respectively) (Yang et al. 2014).

One study demonstrated the use of succinic acidmodified dextran to form GnRH-decorated micelles loaded with cisplatin for breast cancer targeting. Results showed better uptake of targeted micelles by MCF-7 cells in vitro and in vivo in comparison to non-targeted micelles in addition to higher cytotoxicity of the targeted micelles in vivo in comparison to non-targeted micelles (tumor volume of
$370 \mathrm{~mm}^{3}$ vs. $467 \mathrm{~mm}^{3}$, respectively, after 20 days of treatment at $10 \mathrm{mg} / \mathrm{kg}$ ) (Li et al. 2015).

An anti-VEGF siRNA and GnRH were attached to either end of PEG. The GnRH-PEG-siRNA conjugates were self-assembled to form nano-micelles upon mixing with polyethylenimine (PEI). Targeted micelles were 50\% more uptaken by GnRH-R overexpressing ovarian cancer cell line A2780 in comparison to non-targeted micelles. Targeted micelles caused a greater VEGF expression inhibition $(139.4 \mathrm{pg} / \mathrm{mL})$ than non-targeted micelles $(214.1 \mathrm{pg} / \mathrm{mL})$ (Kim et al. 2008).

In another study, PLGA-PEG-GnRH conjugates were self-assembled to form a micellar architecture that encapsulated DTX for prostate cancer treatment. GnRHtargeted micelles were uptaken 1.5 -fold more by LNCaP cells than non-targeted micelles after $1 \mathrm{~h}$ and showed a significantly higher cytotoxicity to LNCaP cells $\left(\mathrm{IC}_{50}=1.28\right.$ $\mu \mathrm{g} / \mathrm{mL}$ ) than non-targeted micelles $\left(\mathrm{IC}_{50}=3.95 \mu \mathrm{g} / \mathrm{mL}\right.$ ) and free DTX $\left(\mathrm{IC}_{50}=4.98 \mu \mathrm{g} / \mathrm{mL}\right)$. Targeted micelles induced apoptosis in $62 \%$ of cells in comparison to $25 \%$ apoptosis in DTX-treated cells and 56\% apoptosis in cells treated with untargeted DDS (Cao et al. 2016).

\section{Lipid-based nanoformulations}

Lipid-based nanoformulations are biodegradable, biologically inert nanoparticles, and have limited intrinsic toxicity (Li et al. 2017). Liposomes are one of the most common types of lipid-based nanoformulations that are made from one or more single amphiphilic lipids bilayers. Figure 1.7 shows an illustration of a liposome decorated with GnRH.

He et al. fabricated PEGylated mitoxantrone (MTO)loaded liposomes and decorated them with a natural $\mathrm{GnRH}$ peptide via a thioether bond. MCF-7 cells preferentially uptook the targeted liposomes in comparison to the non-targeted ones. The improved internalization and cytotoxicity of targeted liposomes were dependent on MTO dose, and at certain concentrations range, both targeted and non-targeted liposomes had almost similar cytotoxicity (He et al. 2010). In tumor-bearing mice, targeted liposomes caused a more significant reduction of tumor volume than free MTO and non-targeted liposomes. After 2 weeks of treating tumor-bearing mice, tumors developed resistance to free MTO but not to the targeted liposomes. Targeted liposomes had less impact on body weight in comparison to free MTO (Zhang et al. 2018).

The Minko group fabricated a nanostructured lipid carrier (NLC) for the pulmonary delivery of anticancer drugs and siRNAs. The NLC encapsulated either DOX or 
PTX and was electrostatically bound to two siRNAs: one to silence the multidrug resistance-associated protein 1 (MRP1) gene to suppress drug efflux pumps, and another one to target BCL2 mRNA to inhibit antiapoptotic defense. Furthermore, the NLCs were conjugated with a GnRH peptide $\left(\left[\mathrm{Q}^{1}\right]\left[\mathrm{k}^{6}\left(\mathrm{c}^{6}\right)\right]\left[\mathrm{P}^{9}-\mathrm{NEt}\right] \mathrm{GnRH}\right)$ for active targeting. After inhalation, the NLC successfully delivered the payload to lung cancer cells which resulted in a significant tumor growth inhibition as well as reduced side effects. The targeted NLC was three to seven times more effective than gefitinib, a standard treatment for NSCLC. Intravenous administration of PTX decreased the tumor volume 1.1 times compared to 1.3 times reduction after treatment with NLC-PTX and 1.9 times following treatment with NLC-siRNA via inhalation. The combination of NLC with siRNA and PTX through inhalation decreased the tumor size 5.6 times (Taratula et al. 2013a).

\section{Inorganic nanoparticles}

Nanotechnology advancement has led to the development of non-toxic, hydrophilic, and biocompatible inorganic nanoparticles. One of their advantages over organic nanoparticles is their high stability which makes them promising platforms for targeted drug delivery (Paul \& Sharma 2010).

Taratula et al. attached a GnRH peptide derivative $\left(\left[\mathrm{Q}^{1}\right]\left[\mathrm{k}^{6}\left(\mathrm{c}^{6}\right)\right]\left[\mathrm{P}^{9}-\mathrm{NEt}\right] \mathrm{GnRH}\right)$ to the surface of mesoporous silica nanoparticles (MSN) via a PEG spacer. The MSNs incorporated DOX and cisplatin inside their pores as well as two siRNAs for inhibition of efflux pump-dependent or -independent cellular drug resistance. Following the inhalation of the DDS, it accumulated mainly in the lungs with a minimal escape to the systemic circulation and other body organs (Taratula et al. 2011a).

In one study, SPIONs were coated with oleic acid, poly(maleic anhydride-alt-1-octadecene), and PEI. Nanoparticles were conjugated with GnRH peptide and loaded with DOX. DOX was released at conditions similar to the acidic TME, and the whole DDS was efficiently uptaken by DOX-resistant ovarian cancer cells. Applying alternating magnetic field induced heat generation by SPIONs, which enhanced the antitumor effect of DOX (Taratula et al. 2013b).

$\mathrm{Hu}$ et al. fabricated GnRH-conjugated PEG-coated $\mathrm{Fe}_{3} \mathrm{O}_{4}$ nanoparticles aiming to increase their stability, hydrophilicity, and biocompatibility. After $1 \mathrm{~h}$ of incubation with MDA-MB-231 breast cancer cells, the GnRH-conjugated nanoparticles were uptaken two times more than the non-conjugated nanoparticles and only a few nanoparticles were uptaken by normal breast cells. While large clusters of nanoparticles entered the cells by receptor-mediated endocytosis (a very slow process), small clusters of nanoparticles entered the cells by mechanisms other than receptor-mediated endocytosis, such as direct penetration. Furthermore, it was shown that in the absence of GnRH-R, large clusters might enter cells by phagocytosis (Hu et al. 2018).

A research group fabricated iron oxide nanoparticles loaded with PTX and coated with a polymer, which was then decorated with two targeting ligands: one for GnRH-R and one for urokinase-type plasminogen activator receptor (uPAR). Dually targeted nanoparticles accumulated more in PC-3 prostate cancer cells than mono-targeted nanoparticles and non-targeted ones. Dually targeted nanoparticles were two times more cytotoxic to PC-3 cells than mono-targeted nanoparticles and three times more cytotoxic than non-targeted nanoparticles and free PTX (Ahmed et al. 2017).

Inorganic nanoparticles can be used as therapeutic agents in addition to their role as drug carriers. In this context, face-centered cubic (fcc) FePt nanoparticles were decorated with GnRH peptides and tested in ovarian cancer cell lines. Nanoparticles were preferentially uptaken by cancer cells where they released free iron inside cancer cells. The free iron catalyzed hydrogen peroxide decomposition into ROS, which disrupted cell membranes and caused cell death (Xu et al. 2009).

Kakar et al. conjugated a GnRH analog to the surface of $\mathrm{Fe}_{3} \mathrm{O}_{4}$ nanoparticles. MCF-7 and MDA-MB-231 breast cancer cell lines preferentially uptook the GnRHconjugated nanoparticles leading to a dose-dependent cell death. The maximum cell death (95-98\%) was achieved with GnRH-conjugated nanoparticles at concentrations of 0.5 and $1 \mu \mathrm{M}$. Cell death was due to the release of free iron from $\mathrm{Fe}_{3} \mathrm{O}_{4}$ in the acidic $\mathrm{pH}$ of lysosomes (Kakar et al. 2008).

Leuschner et al. constructed SPIONs decorated with either GnRH (primary sequence) or $\beta C G$ for the detection of breast cancer metastasis. In MDA-MB-435S cells, GnRHtargeted SPIONs showed higher accumulation in breast cancer cells compared to $\beta C$ G-targeted and non-targeted SPIONs. Moreover, GnRH-SPIONs achieved higher iron oxide concentration in cancer cells and less accumulation in macrophages in comparison to $\beta C G$-targeted and nontargeted SPIONs. In in vivo studies, GnRH-SPIONs showed a higher accumulation in tumor tissue than non-targeted SPIONs (59.1\% vs $8 \%)$. Metastatic lung tissues were able to uptake only the GnRH-SPIONs and not the non-targeted nanoparticles (Leuschner et al. 2006).
(C) 2021 Society for Endocrinology Published by Bioscientifica Ltd. Printed in Great Britain 


\section{Nanogels}

Nanogels are hydrogel nanoparticles holding a great amount of water due to bearing several hydrophilic functional groups. Structurally, they are cross-linked hydrophilic polymer chains through either physical or chemical bonds. They are promising platforms for anticancer applications although their formulation is associated with several challenges (Mohapatra et al. 2019). Figure 1.8 shows an illustration of a nanogel particle conjugated to GnRH.

Nukolova et al. fabricated a PEG-modified polymethacrylic acid (PMAA) block copolymer (PEG-bPMAA) loaded with cisplatin and decorated with [D-Lys ${ }^{6}$ ] GnRH via a PEG linker. Nanogels were stable in PBS or plasma without aggregation for at least 15 days. GnRHR-positive ovarian cancer cell line, A2780, uptook more targeted nanogels (47\%) than non-targeted nanogels (3\%) after $30 \mathrm{~min}$. In addition, targeted nanogels showed a higher accumulation of cisplatin and a stronger anticancer activity than non-targeted ones. However, free cisplatin showed higher accumulation than targeted nanogels. In nude mice carrying xenografts of human ovarian tumor, the GnRH-targeted nanogels showed a tumor inhibition up to $75 \%$ on the second day of treatment, and that inhibition remained steady for 20 days. For free cisplatin and non-targeted nanogels, maximum tumor inhibition was 50\%. Targeted nanogels were well tolerated and mice did not experience significant weight changes (Nukolova et al. 2013).

\section{Expert opinion and discussion}

The overexpression of GnRH in many cancers encouraged researchers to develop numerous GnRH-conjugated DDSs targeting cancer cells via the GnRH-R. Table 2 is a summary of the promising GnRH-R-targeted delivery systems at different stages of development. Preclinical studies showed high selectivity of these targeted DDSs toward cancer cells overexpressing GnRH-R in addition to high cytotoxicity in comparison to non-targeted systems. While most of the designed DDSs were tested in vitro, some were also examined in vivo, and two progressed to the clinical trials. PDCs have the advantages of overcoming the interstitial tumor pressure in reaching the tumor interior, are easy to synthesize and relatively cheap. However, a major setback for PDCs is the low metabolic stability of the peptide that can markedly affect the pharmacological behavior of the payload and successful translation to the clinic.
As a result, only very few PDCs are available in the market. Zoptarelin DOX was one of the few successful GnRHbased PDCs that underwent Phase II clinical trials for different types of cancers including ovarian, endometrial, prostate, breast, and bladder, showing promising results. This PDC reached Phase III clinical trials for endometrial cancer. However, it failed due to its inability to extend overall survival or improving the safety profile compared to free DOX. Reviewing early preclinical investigations of this PDC, the failure could be plausibly due to the GnRH analog's and the linker's lack of sufficient stability in plasma prior to reaching cancer cells. EP-100 a GnRHbased oncolytic peptide also reached Phase II clinical trial for advanced ovarian cancer in combination with PTX. However, trials were discontinued on this combination, suggesting its failure in Phase II clinical trials. The failure is speculated to be due to the use of the slightly modified GnRH-R ligand ([D-Lys 6$]$ GnRH) which might not have high metabolic stability in plasma. EP-100 is now under preclinical investigations to be used in combination with other therapeutics aiming to enhance their efficacy. Recent in vitro results from its combination with an anti-PD-L1 antibody have been promising in ovarian cancer cells.

While no other GnRH-R targeted DDS has reached clinical trials yet, ample research has been conducted on the development of advanced delivery platforms not only for therapeutic but also for diagnostic applications. Several GnRH-conjugated imaging agents provided insight into the effectiveness of GnRH peptides to cause higher accumulation of the conjugates in cancer cells for a period of time sufficient for imaging.

For therapeutic applications, an increasing number of investigations are carried out to develop delivery systems based on polymeric nanoparticles. In this review, a large number of studies were found to be related to this class of DDSs. Of eight studies discussed herein, only three proceeded to animal testing. One of them included a GnRH derivative that was synthesized by Minko group which was bearing the highest number of modified amino acids compared to the derivatives used in other studies. Several DDSs were developed by this group using this highly stable GnRH peptide, and all were reported to be successful in preclinical investigations. In one of these studies, citric acid was used as a linker that allowed versatile attachment of multiple targeting or therapeutic molecules to the polymer. Through this promising strategy, it was discovered that the higher number of targeting molecules can lead to stronger anticancer effects in tumor models in animals. In line with this report, an independent study where a PLGA-based platform was used also showed more
(C) 2021 Society for Endocrinology Published by Bioscientifica Ltd. Printed in Great Britain 


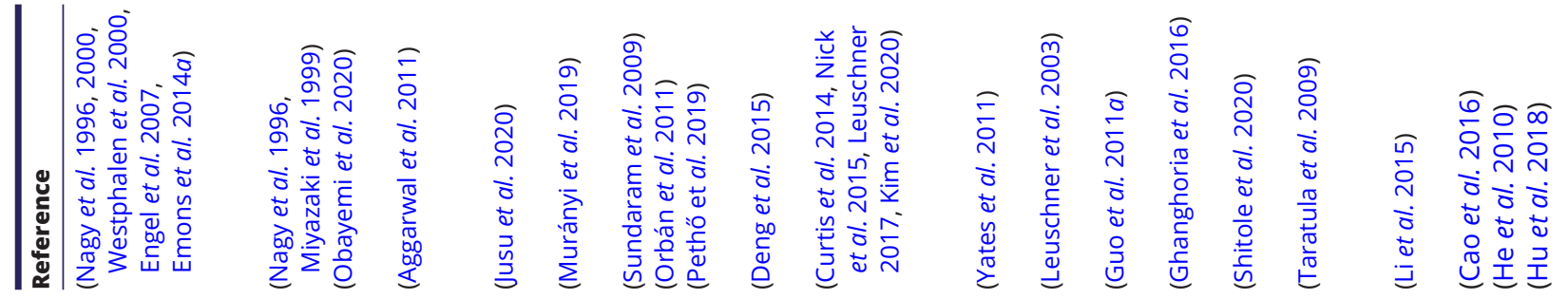
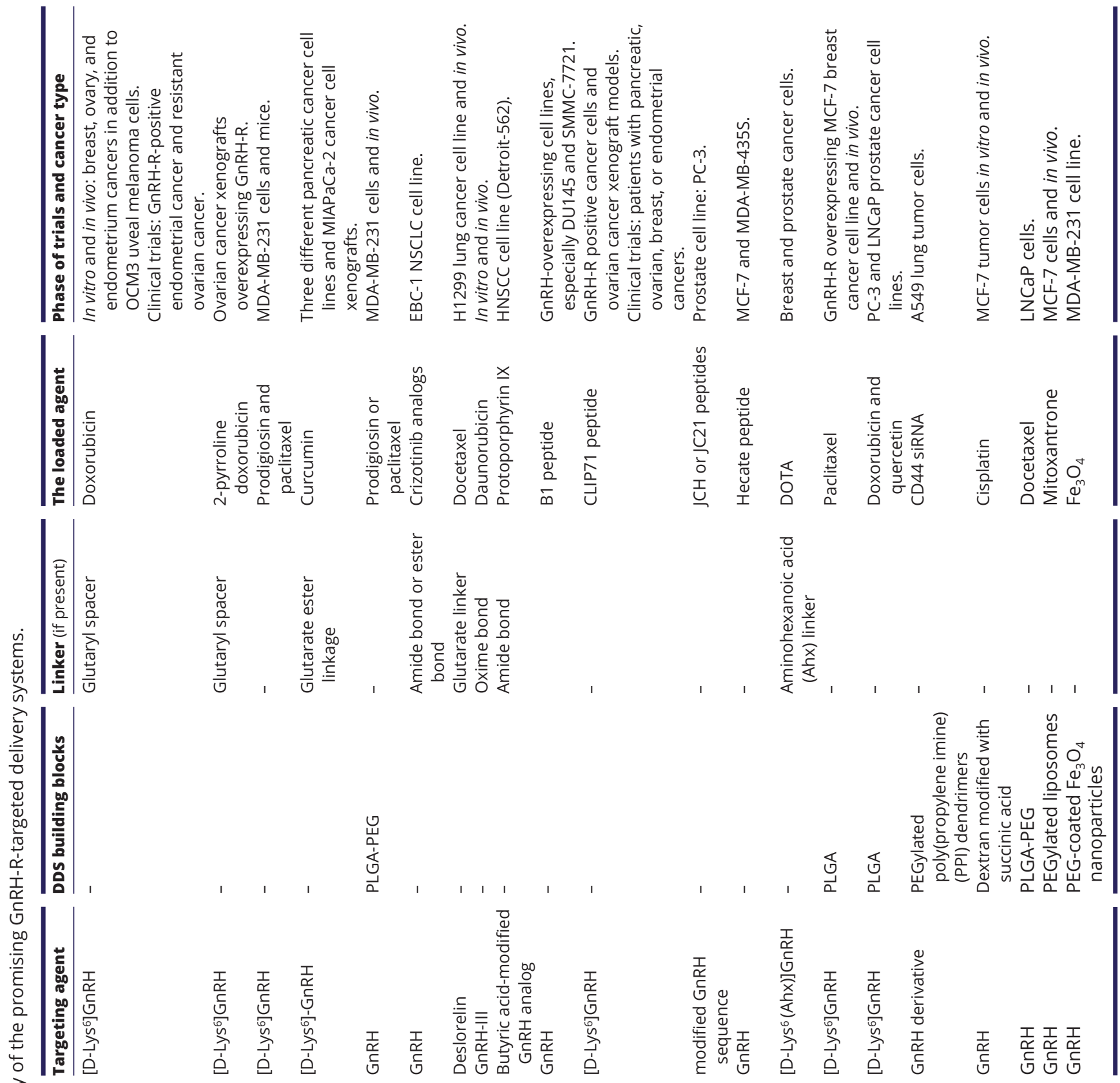

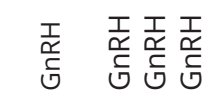
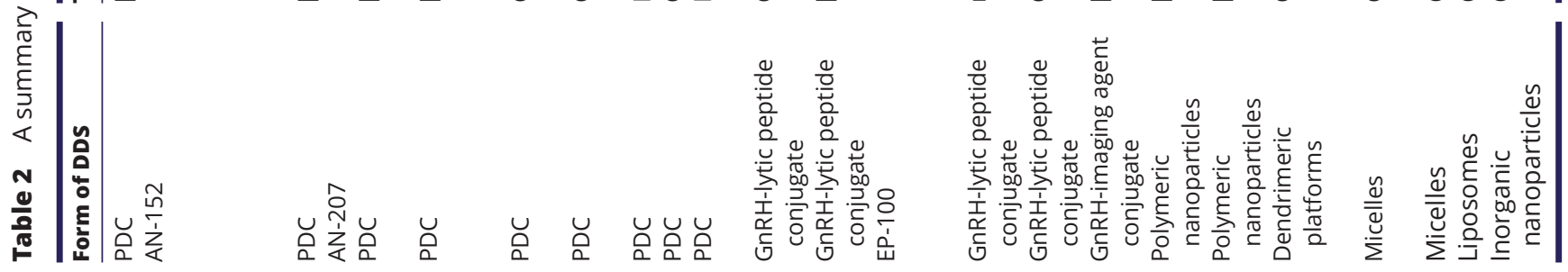
copies of GnRH peptide as the targeting moiety results in an increased uptake and hence, more cytotoxicity in vitro.

The review of literature on GnRH-R-mediated targeting revealed that the combination of two therapeutic molecules usually yields better results than using monotherapy in these types of DDSs. In several studies, dendrimers were used to deliver siRNAs in combination with other agents effectively. As gene vectors of low toxicity and significant transfection efficiency, GnRH-modified dendrimers were also used to deliver siRNAs alone or in combination with cytotoxic agents. For example, the combination of siRNA against CD44 gene and PTX showed a strong antitumor effect in ovarian cancer cells. While all in vitro results indicated enhanced efficacy of the DDS, none of them was tested in animal models, and hence, a thorough conclusion of their pharmacological behavior would not be possible.

Micelles are versatile platforms and were one of the largely developed GnRH-R targeted DDSs. They were employed to encapsulate different therapeutic molecules and they were shown to be relatively promising carriers for GnRH-R targeted delivery of therapeutic molecules to cancer cells, in cell-based assays and animal models (three of six studies were tested in animals). However, due to the low metabolic stability of micelles, their pharmacokinetic profile should be specifically investigated to ensure an adequate circulation time, and thereby, efficient delivery of the therapeutic agents to cancer cells is achieved.

Among lipid-based nanoformulations, two successful platforms were highlighted that were both tested in the relevant animal models. One was a GnRH-modified liposome that not only cased tumor growth reduction but also inhibited resistance to chemotherapy and decreased side effects. Another promising result was obtained from using the combination of two siRNAs with PTX in a nanolipid carrier in animal models of lung cancer. This study and some other studies suggest that the combination of a chemotherapeutic agent and a siRNA for inhibition of drug resistance in a GnRH-R-targeted setting might be a successful strategy to enhance potentials for tumor eradication.

Inorganic nanoparticles (mainly iron oxide nanoparticles) are largely investigated for GnRH-R-targeted delivery of therapeutic agents. They exert their antitumor effects by the generation of heat or ROS in addition to their role as drug carriers. Nonetheless, none of these targeted DDSs were tested in animal models.

Although a considerable effort went into the development of complex delivery systems, very little attention was directed into the design and synthesis of novel GnRH derivatives with high stability and binding affinity for GnRH-R, suitable for targeting. Apart from those studies conducted by Minko group, where a substantially modified GnRH derivative was used (modifications at N-terminus, C-terminus, and the middle of the sequence), in most other studies, a slightly modified analog ([D-Lys 6 GnRH) was employed including the two PDCs that proceeded to clinical trials. Although this derivative has been reported to have higher metabolic stability than the natural ligand, due to lacking sufficient stability for targeting purposes, both therapeutics bearing this peptide (Zoptarelin DOX and EP-100) that reached clinical trials failed to show any improvements in their side effect profiles or anticancer efficacies. These findings warrant further investigations for developing more stable and potent GnRH targeting moieties as well as more efficient DDSs for applications in cancer therapy.

\section{Conclusion}

Several multifunctional and advanced GnRH-R-targeted DDSs have been developed to deliver various types of agents, including chemotherapeutic agents, oligonucleotides, photoactive drugs, and imaging agents. Research on the development of innovative platforms for GnRH-R targeted delivery is highly demanded to widen current treatment options or explore new therapeutics for different types of GnRH-Roverexpressing cancers. In thesenew developments, however, more in-depth investigation on the stability of the GnRH derivative and the whole construct in addition to their receptor binding affinity and hence targeting potential is required. These studies should be complemented with more thorough preclinical studies to obtain detailed knowledge of the stability, pharmacokinetics, tumor and normal tissue biodistribution, and acute and long-term safety profiles of the new GnRH-R-targeted DDSs prior to clinical trials.

\section{Declaration of interest}

The authors declare that there is no conflict of interest that could be perceived as prejudicing the impartiality of this review.

\section{Funding}

This work did not receive any specific grant from any funding agency in the public, commercial, or not-for-profit sector. (c) 2021 Society for Endocrinology Published by Bioscientifica Ltd. Printed in Great Britain 


\section{Acknowledgements}

The authors would like to acknowledge the National Breast Cancer Foundation Research fellowship and grant to Dr Pegah Varamini (PF-16-007).

\section{References}

Aggarwal S, Ndinguri MW, Solipuram R, Wakamatsu N, Hammer RP, Ingram D \& Hansel W 2011 [DLys(6)]-luteinizing hormone releasing hormone-curcumin conjugate inhibits pancreatic cancer cell growth in vitro and in vivo. International Journal of Cancer 129 1611-1623. (https://doi.org/10.1002/ijc.26132)

Ahmed MSU, Salam AB, Yates C, Willian K, Jaynes J, Turner T \& Abdalla MO 2017 Double-receptor-targeting multifunctional iron oxide nanoparticles drug delivery system for the treatment and imaging of prostate cancer. International Journal of Nanomedicine $\mathbf{1 2}$ 6973-6984. (https://doi.org/10.2147/IJN.S139011)

Bae YH \& Park K 2011 Targeted drug delivery to tumors: myths, reality and possibility. Journal of Controlled Release 153 198-205. (https://doi. org/10.1016/j.jconrel.2011.06.001)

Bazak R, Houri M, Achy SE, Hussein W \& Refaat T 2014 Passive targeting of nanoparticles to cancer: a comprehensive review of the literature. Molecular and Clinical Oncology 2 904-908. (https://doi.org/10.3892/ mco.2014.356)

Bolhassani A, Javanzad S, Saleh T, Hashemi M, Aghasadeghi MR \& Sadat SM 2014 Polymeric nanoparticles: potent vectors for vaccine delivery targeting cancer and infectious diseases. Human Vaccines and Immunotherapeutics 10 321-332. (https://doi.org/10.4161/hv.26796)

Cao LB, Zeng S \& Zhao W 2016 Highly stable pegylated poly(lactic-coglycolic acid) (PLGA) nanoparticles for the effective delivery of docetaxel in prostate cancers. Nanoscale Research Letters 11 305-305. (https://doi.org/10.1186/s11671-016-1509-3)

Chandna P, Khandare JJ, Ber E, Rodriguez-Rodriguez L \& Minko T 2010 Multifunctional tumor-targeted polymer-peptide-drug delivery system for treatment of primary and metastatic cancers. Pharmaceutical Research 27 2296-2306. (https://doi.org/10.1007/s11095-010-0235-2)

Chen A, Yahalom D, Ben-Aroya N, Kaganovsky E, Okon E \& Koch Y 1998 A second isoform of gonadotropin-releasing hormone is present in the brain of human and rodents. FEBS Letters 435 199-203. (https://doi. org/10.1016/s0014-5793(98)01064-3)

Curtis KK, Sarantopoulos J, Northfelt DW, Weiss GJ, Barnhart KM, Whisnant JK, Leuschner C, Alila H, Borad MJ \& Ramanathan RK 2014 Novel LHRH-receptor-targeted cytolytic peptide, EP-100: first-inhuman phase I study in patients with advanced LHRH-receptorexpressing solid tumors. Cancer Chemotherapy and Pharmacology $\mathbf{7 3}$ 931-941. (https://doi.org/10.1007/s00280-014-2424-x)

Deng X, Klussmann S, Wu GM, Akkerman D, Zhu YQ, Liu Y, Chen H, Zhu P, Yu BZ \& Zhang GL 2008 Effect of LHRH-PE40 on target cells via LHRH receptors. Journal of Drug Targeting 16 379-388. (https://doi. org/10.1080/10611860802102324)

Deng X, Qiu Q, Ma K, Huang W \& Qian H 2015 Synthesis and in vitro anti-cancer evaluation of luteinizing hormone-releasing hormoneconjugated peptide. Amino Acids 47 2359-2366. (https://doi. org/10.1007/s00726-015-2021-2)

Dharap SS, Qiu B, Williams GC, Sinko P, Stein S \& Minko T 2003 Molecular targeting of drug delivery systems to ovarian cancer by BH3 and LHRH peptides. Journal of Controlled Release 91 61-73. (https://doi. org/10.1016/s0168-3659(03)00209-8)

Dharap SS, Wang Y, Chandna P, Khandare JJ, Qiu B, Gunaseelan S, Sinko PJ, Stein S, Farmanfarmaian A \& Minko T 2005 Tumor-specific targeting of an anticancer drug delivery system by LHRH peptide. PNAS 102 12962-12967. (https://doi.org/10.1073/pnas.0504274102)

Dondi D, Festuccia C, Piccolella M, Bologna M \& Motta M 2006 GnRH agonists and antagonists decrease the metastatic progression of human prostate cancer cell lines by inhibiting the plasminogen activator system. Oncology Reports 15 393-400. (https://doi. org/10.3892/or.15.2.393)

Eicke N, Günthert AR, Viereck V, Siebold D, Béhé M, Becker T, Emons G \& Gründker C 2005 GnRH-II receptor-like antigenicity in human placenta and in cancers of the human reproductive organs. European Journal of Endocrinology 153 605-612. (https://doi.org/10.1530/eje.1.02005)

Eidne KA, Flanagan CA, Harris NS \& Millar RP 1987 Gonadotropinreleasing hormone (GnRH)-binding sites in human breast cancer cell lines and inhibitory effects of GnRH antagonists. Journal of Clinical Endocrinology and Metabolism 64 425-432. (https://doi.org/10.1210/ jcem-64-3-425)

Emons G, Müller V, Ortmann O \& Schulz KD 1998 Effects of LHRHanalogues on mitogenic signal transduction in cancer cells. Journal of Steroid Biochemistry and Molecular Biology 65 199-206. (https://doi. org/10.1016/s0960-0760(97)00189-1)

Emons G, Gründker C, Günthert AR, Westphalen S, Kavanagh J \& Verschraegen C $2003 \mathrm{GnRH}$ antagonists in the treatment of gynecological and breast cancers. Endocrine-Related Cancer 10 291-299. (https://doi.org/10.1677/erc.0.0100291)

Emons G, Kaufmann M, Gorchev G, Tsekova V, Gründker C, Günthert AR, Hanker LC, Velikova M, Sindermann H, Engel J, et al. 2010 Dose escalation and pharmacokinetic study of AEZS-108 (AN-152), an LHRH agonist linked to doxorubicin, in women with LHRH receptor-positive tumors. Gynecologic Oncology 119 457-461. (https://doi.org/10.1016/j. ygyno.2010.08.003)

Emons G, Gorchev G, Sehouli J, Wimberger P, Stähle A, Hanker L, Hilpert F, Sindermann H, Gründker C \& Harter P 2014a Efficacy and safety of AEZS-108 (INN: zoptarelin doxorubicin acetate) an LHRH agonist linked to doxorubicin in women with platinum refractory or resistant ovarian cancer expressing LHRH receptors: a multicenter phase II trial of the ago-study group (AGO GYN 5). Gynecologic Oncology 133 427-432. (https://doi.org/10.1016/j.ygyno.2014.03.576)

Emons G, Gorchev G, Harter P, Wimberger P, Stähle A, Hanker L, Hilpert F, Beckmann MW, Dall P, Gründker C, et al. 2014b Efficacy and safety of AEZS-108 (LHRH agonist linked to doxorubicin) in women with advanced or recurrent endometrial cancer expressing LHRH receptors: a multicenter phase 2 trial (AGO-GYN5). International Journal of Gynecological Cancer 24 260-265. (https://doi.org/10.1097/ IGC.0000000000000044)

Engel JB, Schally AV, Dietl J, Rieger L \& Hönig A 2007 Targeted therapy of breast and gynecological cancers with cytotoxic analogues of peptide hormones. Molecular Pharmaceutics 4 652-658. (https://doi. org/10.1021/mp0700514)

Fekete M, Wittliff JL \& Schally AV 1989 Characteristics and distribution of receptors for [D-TRP6]-luteinizing hormone-releasing hormone, somatostatin, epidermal growth factor, and sex steroids in 500 biopsy samples of human breast cancer. Journal of Clinical Laboratory Analysis 3 137-147. (https://doi.org/10.1002/jcla.1860030302)

Fernald RD \& White RB 1999 Gonadotropin-releasing hormone genes: phylogeny, structure, and functions. Frontiers in Neuroendocrinology 20 224-240. (https://doi.org/10.1006/frne.1999.0181)

Fister S, Günthert AR, Emons G \& Gründker C 2007 Gonadotropinreleasing hormone type II antagonists induce apoptotic cell death in human endometrial and ovarian cancer cells in vitro and in vivo. Cancer Research 67 1750-1756. (https://doi.org/10.1158/0008-5472. CAN-06-3222)

Fodor K, Dobos N, Schally A, Steiber Z, Olah G, Sipos E, Szekvolgyi L \& Halmos G 2020 The targeted LHRH analog AEZS-108 alters expression of genes related to angiogenesis and development of metastasis in uveal melanoma. Oncotarget 11 175-187. (https://doi.org/10.18632/ oncotarget.27431)

Fost C, Duwe F, Hellriegel M, Schweyer S, Emons G \& Grundker C 2011 Targeted chemotherapy for triple-negative breast cancers via LHRH receptor. Oncology Reports 25 1481-1487. (https://doi.org/10.3892/ or.2011.1188) (c) 2021 Society for Endocrinology Published by Bioscientifica Ltd. Printed in Great Britain 
Ghanghoria R, Tekade RK, Mishra AK, Chuttani K \& Jain NK 2016 Luteinizing hormone-releasing hormone peptide tethered nanoparticulate system for enhanced antitumoral efficacy of paclitaxel. Nanomedicine 11 797-816. (https://doi.org/10.2217/nnm.16.19)

Goodwin D, Varamini P, Simerska P \& Toth I 2015 Stability, permeability and growth-inhibitory properties of gonadotropin-releasing hormone liposaccharides. Pharmaceutical Research 32 1570-1584. (https://doi. org/10.1007/s11095-014-1558-1)

Gründker C \& Emons G 2017 The role of gonadotropin-releasing hormone in cancer cell proliferation and metastasis. Frontiers in Endocrinology 8 187-187. (https://doi.org/10.3389/fendo.2017.00187)

Gründker C, Völker P \& Emons G 2001 Antiproliferative signaling of luteinizing hormone-releasing hormone in human endometrial and ovarian cancer cells through $G$ protein alpha(I)-mediated activation of phosphotyrosine phosphatase. Endocrinology 142 2369-2380. (https:// doi.org/10.1210/endo.142.6.8190)

Grundker C, Gunthert AR, Westphalen S \& Emons G 2002 Biology of the gonadotropin-releasing hormone system in gynecological cancers. European Journal of Endocrinology 146 1-14. (https://doi.org/10.1530/ eje.0.1460001)

Gründker C, Günthert AR, Millar RP \& Emons G 2002a Expression of gonadotropin-releasing hormone II (GnRH-II) receptor in human endometrial and ovarian cancer cells and effects of GnRH-II on tumor cell proliferation. Journal of Clinical Endocrinology and Metabolism $\mathbf{8 7}$ 1427-1430. (https://doi.org/10.1210/jcem.87.3.8437)

Gründker C, Völker P, Griesinger F, Ramaswamy A, Nagy A, Schally AV \& Emons G 2002b Antitumor effects of the cytotoxic luteinizing hormone-releasing hormone analog AN-152 on human endometrial and ovarian cancers xenografted into nude mice. American Journal of Obstetrics and Gynecology 187 528-537. (https://doi.org/10.1067/ mob.2002.124278)

Gründker C, Ernst J, Reutter MD, Ghadimi BM \& Emons G 2011 Effective targeted chemotherapy using AEZS-108 (AN-152) for LHRH receptorpositive pancreatic cancers. Oncology Reports 26 629-635. (https://doi. org/10.3892/or.2011.1340)

Gründker C, Bauerschmitz G, Schubert A \& Emons G 2016 Invasion and increased expression of S100A4 and CYR61 in mesenchymal transformed breast cancer cells is downregulated by GnRH. International Journal of Oncology 48 2713-2721. (https://doi. org/10.3892/ijo.2016.3491)

Guo H, Gallazzi F, Sklar LA \& Miao Y 2011a A novel indium-111-labeled gonadotropin-releasing hormone peptide for human prostate cancer imaging. Bioorganic and Medicinal Chemistry Letters 21 5184-5187. (https://doi.org/10.1016/j.bmcl.2011.07.055)

Guo H, Lu J, Hathaway H, Royce ME, Prossnitz ER \& Miao Y 2011b Synthesis and evaluation of novel gonadotropin-releasing hormone receptor-targeting peptides. Bioconjugate Chemistry 22 1682-1689. (https://doi.org/10.1021/bc200252j)

Halmos G, Arencibia JM, Schally AV, Davis R \& Bostwick DG 2000 High incidence of receptors for luteinizing hormone-releasing hormone (LHRH) and LHRH receptor gene expression in human prostate cancers. Journal of Urology 163 623-629. (https://doi.org/10.1016/ S0022-5347(05)67947-5)

Hanafy NAN, El-Kemary M \& Leporatti S 2018 Micelles structure development as a strategy to improve smart cancer therapy. Cancers $\mathbf{1 0}$ 238. (https://doi.org/10.3390/cancers10070238)

Harrison GS, Wierman ME, Nett TM \& Glode LM 2004 Gonadotropinreleasing hormone and its receptor in normal and malignant cells. Endocrine-Related Cancer 11 725-748. (https://doi.org/10.1677/ erc.1.00777)

He Q \& Shi J 2014 MSN anti-cancer nanomedicines: chemotherapy enhancement, overcoming of drug resistance, and metastasis inhibition. Advanced Materials 26 391-411. (https://doi.org/10.1002/ adma.201303123)

He Y, Zhang L \& Song C 2010 Luteinizing hormone-releasing hormone receptor-mediated delivery of mitoxantrone using LHRH analogs modified with pegylated liposomes. International Journal of Nanomedicine 5 697-705. (https://doi.org/10.2147/ijn.s12129)

Hislop JN, Madziva MT, Everest HM, Harding T, Uney JB, Willars GB, Millar RP, Troskie BE, Davidson JS \& McArdle CA 2000 Desensitization and internalization of human and Xenopus gonadotropin-releasing hormone receptors expressed in alphaT4 pituitary cells using recombinant adenovirus. Endocrinology 141 4564-4575. (https://doi. org/10.1210/endo.141.12.7813)

Hu J, Obayemi JD, Malatesta K, Košmrlj A \& Soboyejo WO 2018 Enhanced cellular uptake of LHRH-conjugated PEG-coated magnetite nanoparticles for specific targeting of triple negative breast cancer cells. Materials Science and Engineering: C, Materials for Biological Applications 88 32-45. (https://doi.org/10.1016/j.msec.2018.02.017)

Hu J, Obayemi J, Malatesta K, Yurkow E, Adler D \& Soboyejo W 2020 Luteinizing hormone-releasing hormone (LHRH) conjugated magnetite nanoparticles as MRI contrast agents for breast cancer imaging. Applied Sciences 10 5175. (https://doi.org/10.3390/ app10155175)

Imai A, Ohno T, Iida K, Fuseya T, Furui T \& Tamaya T 1994 Gonadotropinreleasing hormone receptor in gynecologic tumors. Frequent expression in adenocarcinoma histologic types. Cancer 74 2555-2561. (https://doi.org/10.1002/1097-0142(19941101)74:9<2555::aidcncr2820740925>3.0.co;2-x)

Jusu SM, Obayemi JD, Salifu AA, Nwazojie CC, Uzonwanne V, Odusanya OS \& Soboyejo WO 2020 Drug-encapsulated blend of PLGAPEG microspheres: in vitro and in vivo study of the effects of localized/targeted drug delivery on the treatment of triple-negative breast cancer. Scientific Reports 10 14188. (https://doi.org/10.1038/ s41598-020-71129-0)

Kakar SS, Jin H, Hong B, Eaton JW \& Kang KA 2008 LHRH receptor targeted therapy for breast cancer. Advances in Experimental Medicine and Biology 614 285-296. (https://doi.org/10.1007/978-0-387-749112_32)

Karten MJ \& Rivier JE 1986 Gonadotropin-releasing hormone analog design. Structure-function studies toward the development of agonists and antagonists: rationale and perspective. Endocrine Reviews 7 44-66. (https://doi.org/10.1210/edrv-7-1-44)

Kasten TL, White SA, Norton TT, Bond CT, Adelman JP \& Fernald RD 1996 Characterization of two new preproGnRH mRNAs in the tree shrew: first direct evidence for mesencephalic GnRH gene expression in a placental mammal. General and Comparative Endocrinology 104 7-19. (https://doi.org/10.1006/gcen.1996.0135)

Kesharwani P, Jain K \& Jain NK 2014 Dendrimer as nanocarrier for drug delivery. Progress in Polymer Science 39 268-307. (https://doi. org/10.1016/j.progpolymsci.2013.07.005)

Khandare JJ, Chandna P, Wang Y, Pozharov VP \& Minko T 2006 Novel polymeric prodrug with multivalent components for cancer therapy. Journal of Pharmacology and Experimental Therapeutics 317 929-937. (https://doi.org/10.1124/jpet.105.098855)

Khazeni S \& Varamini P 2018 Gonadotropin releasing hormone. In Reference Module in Biomedical Sciences. Amsterdam, Netherlands: Elsevier. (https://doi.org/10.1016/B978-0-12-801238-3.98031-0)

Kim SH, Jeong JH, Lee SH, Kim SW \& Park TG 2008 LHRH receptormediated delivery of siRNA using polyelectrolyte complex micelles self-assembled from siRNA-PEG-LHRH conjugate and PEI. Bioconjugate Chemistry 19 2156-2162. (https://doi.org/10.1021/ bc800249n)

Kim MS, Ma S, Chelariu-Raicu A, Leuschner C, Alila HW, Lee S, Coleman RL \& Sood AK 2020 Enhanced immunotherapy with LHRH-R targeted lytic peptide in ovarian cancer. Molecular Cancer Therapeutics 19 2396-2406. (https://doi.org/10.1158/1535-7163.MCT20-0030)

Kovacs M, Schally AV, Nagy A, Koppan M \& Groot K 1997 Recovery of pituitary function after treatment with a targeted cytotoxic analog of luteinizing hormone-releasing hormone. PNAS 94 1420-1425. (https:// doi.org/10.1073/pnas.94.4.1420) 
Kumar P \& Sharma A 2014 Gonadotropin-releasing hormone analogs: understanding advantages and limitations. Journal of Human Reproductive Sciences 7 170-174. (https://doi.org/10.4103/09741208.142476)

Leuschner C 2017 Targeted oncolytic peptide for treatment of ovarian cancers. International Journal of Cancer Research and Molecular Mechanisms 3 [epub]. (https://doi.org/10.16966/2381-3318.132)

Leuschner C, Enright FM, Gawronska B \& Hansel W 2003 Membrane disrupting lytic peptide conjugates destroy hormone dependent and independent breast cancer cells in vitro and in vivo. Breast Cancer Research and Treatment 78 17-27. (https://doi. $\operatorname{org} / 10.1023 / \mathrm{a}: 1022169525521)$

Leuschner C, Kumar CSSR, Hansel W, Soboyejo W, Zhou J \& Hormes J 2006 LHRH-conjugated magnetic iron oxide nanoparticles for detection of breast cancer metastases. Breast Cancer Research and Treatment 99 163-176. (https://doi.org/10.1007/s10549-006-9199-7)

Li M, Tang Z, Zhang Y, Lv S, Li Q \& Chen X 2015 Targeted delivery of cisplatin by LHRH-peptide conjugated dextran nanoparticles suppresses breast cancer growth and metastasis. Acta Biomaterialia 18 132-143. (https://doi.org/10.1016/j.actbio.2015.02.022)

Li X, Taratula O, Taratula O, Schumann C \& Minko T 2017 LHRH-targeted drug delivery systems for cancer therapy. Mini Reviews in Medicinal Chemistry 17 258-267. (https://doi.org/10.2174/138955751666616101311 1155)

Millar RP 2005 GnRHs and GnRH receptors. Animal Reproduction Science 88 5-28. (https://doi.org/10.1016/j.anireprosci.2005.05.032)

Miller DS, Scambia G, Bondarenko I, Westermann AM, Oaknin A, Oza AM, Lisyanskaya AS, Vergote I, Wenham RM, Temkin SM, et al. 2018 ZoptEC: phase III randomized controlled study comparing zoptarelin with doxorubicin as second line therapy for locally advanced, recurrent, or metastatic endometrial cancer (NCT01767155). Journal of Clinical Oncology 36 5503-5503. (https://doi.org/10.1200/ JCO.2018.36.15_suppl.5503)

Minko T, Patil ML, Zhang M, Khandare JJ, Saad M, Chandna P \& Taratula O 2010 LHRH-targeted nanoparticles for cancer therapeutics. Methods in Molecular Biology 624 281-294. (https://doi. org/10.1007/978-1-60761-609-2_19)

Minko T, Rodriguez-Rodriguez L \& Pozharov V 2013 Nanotechnology approaches for personalized treatment of multidrug resistant cancers. Advanced Drug Delivery Reviews 65 1880-1895. (https://doi. org/10.1016/j.addr.2013.09.017)

Miyazaki M, Schally AV, Nagy A, Lamharzi N, Halmos G, Szepeshazi K \& Armatis P 1999 Targeted cytotoxic analog of luteinizing hormonereleasing hormone AN-207 inhibits growth of OV-1063 human epithelial ovarian cancers in nude mice. American Journal of Obstetrics and Gynecology 180 1095-1103. (https://doi.org/10.1016/s00029378(99)70600-9)

Mohapatra A, Uthaman S \& Park I-K 2019 Chapter 10 - Polyethylene glycol nanoparticles as promising tools for anticancer therapeutics. In Polymeric Nanoparticles as a Promising Tool for Anti-Cancer Therapeutics, pp. 205-231. Eds P Kesharwani, KM Paknikar \& V Gajbhiye. Cambridge, MA, USA: Academic Press. (https://doi.org/10.1016/B9780-12-816963-6.00010-8)

Murányi J, Varga A, Gyulavári P, Pénzes K, Németh CE, Csala M, Pethő L, Csámpai A, Halmos G, Peták I, et al. 2019 Novel crizotinib-GnRH conjugates revealed the significance of lysosomal trapping in GnRHbased drug delivery systems. International Journal of Molecular Sciences 20 5590. (https://doi.org/10.3390/ijms20225590)

Nagy A \& Schally AV 2005 Targeting of cytotoxic luteinizing hormonereleasing hormone analogs to breast, ovarian, endometrial, and prostate cancers. Biology of Reproduction 73 851-859. (https://doi. org/10.1095/biolreprod.105.043489)

Nagy A, Schally AV, Armatis P, Szepeshazi K, Halmos G, Kovacs M, Zarandi M, Groot K, Miyazaki M, Jungwirth A, et al. 1996 Cytotoxic analogs of luteinizing hormone-releasing hormone containing doxorubicin or 2-pyrrolinodoxorubicin, a derivative 500-1000 times more potent. PNAS 93 7269-7273. (https://doi.org/10.1073/ pnas.93.14.7269)

Nagy A, Plonowski A \& Schally AV 2000 Stability of cytotoxic luteinizing hormone-releasing hormone conjugate (AN-152) containing doxorubicin 14-O-hemiglutarate in mouse and human serum in vitro: implications for the design of preclinical studies. PNAS 97 829-834. (https://doi.org/10.1073/pnas.97.2.829)

Nian D, Shi P, Sun J, Ren L, Hao X \& Han J 2019 Application of luteinizing hormone-releasing hormone-ferrosoferric oxide nanoparticles in targeted imaging of breast tumors. Journal of International Medical Research 47 1749-1757. (https://doi. org/10.1177/0300060519834457)

Nick AM, Urban R, Gordinier ME, Leuschner C, Rado T, Bavisotto LM, Whisnant J \& Coleman RL 2015 EP-100 + Paclitaxel to overcome taxane resistance in patients with recurrent LHRH-receptor expressing ovarian cancer. Journal of Clinical Oncology 33 5582-5582. (https://doi. org/10.1200/jco.2015.33.15_suppl.5582)

Nomura S, Morimoto Y, Tsujimoto H, Arake M, Harada M, Saitoh D, Hara I, Ozeki E, Satoh A, Takayama E, et al. 2020 Highly reliable, targeted photothermal cancer therapy combined with thermal dosimetry using a near-infrared absorbent. Scientific Reports 109765. (https://doi.org/10.1038/s41598-020-66646-x)

Nukolova NV, Oberoi HS, Zhao Y, Chekhonin VP, Kabanov AV \& Bronich TK 2013 LHRH-targeted nanogels as a delivery system for cisplatin to ovarian cancer. Molecular Pharmaceutics 10 3913-3921. (https://doi.org/10.1021/mp4003688)

Obayemi JD, Salifu AA, Eluu SC, Uzonwanne VO, Jusu SM, Nwazojie CC, Onyekanne CE, Ojelabi O, Payne L, Moore CM, et al. 2020 LHRHconjugated drugs as targeted therapeutic agents for the specific targeting and localized treatment of triple negative breast cancer. Scientific Reports 10 8212. (https://doi.org/10.1038/s41598-020-649791)

Orbán E, Mezo G, Schlage P, Csík G, Kulić Z, Ansorge P, Fellinger E, Möller HM \& Manea M 2011 In vitro degradation and antitumor activity of oxime bond-linked daunorubicin-GnRH-III bioconjugates and DNA-binding properties of daunorubicin-amino acid metabolites. Amino Acids 41 469-483. (https://doi.org/10.1007/s00726-010-0766-1)

Patil ML, Zhang M, Taratula O, Garbuzenko OB, He H \& Minko T 2009 Internally cationic polyamidoamine PAMAM-OH dendrimers for siRNA delivery: effect of the degree of quaternization and cancer targeting. Biomacromolecules 10 258-266. (https://doi.org/10.1021/ bm8009973)

Paul W \& Sharma CP 20108 - Inorganic nanoparticles for targeted drug delivery. In Biointegration of Medical Implant Materials, pp. 204-235. Ed CP Sharma. Sawston, Cambridge, UK: Woodhead Publishing. (https:// doi.org/10.1016/B978-0-08-102680-9.00013-5)

Perrett RM \& McArdle CA 2013 Molecular mechanisms of gonadotropinreleasing hormone signaling: integrating cyclic nucleotides into the network. Frontiers in Endocrinology 4 180-180. (https://doi.org/10.3389/ fendo.2013.00180)

Pethő L, Murányi J, Pénzes K, Gurbi B, Brauswetter D, Halmos G, Csík G \& Mező G 2019 Suitability of GnRH receptors for targeted photodynamic therapy in head and neck cancers. International Journal of Molecular Sciences 20 5027. (https://doi.org/10.3390/ijms20205027)

Rahimipour S, Ben-Aroya N, Ziv K, Chen A, Fridkin M \& Koch Y 2003 Receptor-mediated targeting of a photosensitizer by its conjugation to gonadotropin-releasing hormone analogues. Journal of Medicinal Chemistry 46 3965-3974. (https://doi.org/10.1021/jm020535y)

Ranđelović I, Schuster S, Kapuvári B, Fossati G, Steinkühler C, Mező G \& Tóvári J 2019 Improved in vivo anti-tumor and anti-metastatic effect of GnRH-III-daunorubicin analogs on colorectal and breast carcinoma bearing mice. International Journal of Molecular Sciences 204763. (https://doi.org/10.3390/ijms20194763)

Saad M, Garbuzenko OB, Ber E, Chandna P, Khandare JJ, Pozharov VP \& Minko T 2008 Receptor targeted polymers, dendrimers, liposomes: which nanocarrier is the most efficient for tumor-specific treatment (c) 2021 Society for Endocrinology Published by Bioscientifica Ltd. Printed in Great Britain 
and imaging? Journal of Controlled Release 130 107-114. (https://doi. org/10.1016/j.jconrel.2008.05.024)

Schally AV \& Nagy A 1999 Cancer chemotherapy based on targeting of cytotoxic peptide conjugates to their receptors on tumors. European Journal of Endocrinology 141 1-14. (https://doi.org/10.1530/ eje.0.1410001)

Schumann C, Taratula O, Khalimonchuk O, Palmer AL, Cronk LM, Jones CV, Escalante CA \& Taratula O 2015 ROS-induced nanotherapeutic approach for ovarian cancer treatment based on the combinatorial effect of photodynamic therapy and DJ-1 gene suppression. Nanomedicine 11 1961-1970. (https://doi.org/10.1016/j. nano.2015.07.005)

Schuster S, Biri-Kovács B, Szeder B, Buday L, Gardi J, Szabó Z, Halmos G \& Mező G 2018 Enhanced in vitro antitumor activity of GnRH-IIIdaunorubicin bioconjugates influenced by sequence modification. Pharmaceutics 10 223. (https://doi.org/10.3390/ pharmaceutics10040223)

Shah V, Taratula O, Garbuzenko OB, Taratula OR, Rodriguez-Rodriguez L \& Minko T 2013 Targeted nanomedicine for suppression of CD44 and simultaneous cell death induction in ovarian cancer: an optimal delivery of siRNA and anticancer drug. Clinical Cancer Research 19 6193-6204. (https://doi.org/10.1158/1078-0432.CCR-13-1536)

Shitole AA, Sharma N, Giram P, Khandwekar A, Baruah M, Garnaik B \& Koratkar S 2020 LHRH-conjugated, pegylated, poly-lactide-co-glycolide nanocapsules for targeted delivery of combinational chemotherapeutic drugs docetaxel and quercetin for prostate cancer. Materials Science and Engineering: C, Materials for Biological Applications 114 111035. (https://doi.org/10.1016/j.msec.2020.111035)

Sundaram S, Trivedi R, Durairaj C, Ramesh R, Ambati BK \& Kompella UB 2009 Targeted drug and gene delivery systems for lung cancer therapy. Clinical Cancer Research 15 7299-7308. (https://doi.org/10.1158/10780432.CCR-09-1745)

Suo L, Chang X, Xu N \& Ji H 2019 The anti-proliferative activity of GnRH through downregulation of the Akt/ERK pathways in pancreatic cancer. Frontiers in Endocrinology 10 370. (https://doi.org/10.3389/ fendo.2019.00370)

Szabó I, Manea M, Orbán E, Csámpai A, Bosze S, Szabó R, Tejeda M, Gaál D, Kapuvári B, Przybylski M, et al. 2009 Development of an oxime bond containing daunorubicin-gonadotropin-releasing hormone-III conjugate as a potential anticancer drug. Bioconjugate Chemistry 20 656-665. (https://doi.org/10.1021/bc800542u)

Taheri A, Dinarvand R, Atyabi F, Ahadi F, Nouri FS, Ghahremani MH, Ostad SN, Borougeni AT \& Mansoori P 2011 Enhanced anti-tumoral activity of methotrexate-human serum albumin conjugated nanoparticles by targeting with luteinizing hormone-releasing hormone (LHRH) peptide. International Journal of Molecular Sciences 12 4591-4608. (https://doi.org/10.3390/ijms12074591)

Tang L, Yang X, Yin Q, Cai K, Wang H, Chaudhury I, Yao C, Zhou Q, Kwon M, Hartman JA, et al. 2014 Investigating the optimal size of anticancer nanomedicine. PNAS 111 15344-15349. (https://doi. org/10.1073/pnas.1411499111)

Taratula O, Garbuzenko OB, Kirkpatrick P, Pandya I, Savla R, Pozharov VP, He H \& Minko T 2009 Surface-engineered targeted PPI dendrimer for efficient intracellular and intratumoral siRNA delivery. Journal of Controlled Release 140 284-293. (https://doi.org/10.1016/j. jconrel.2009.06.019)

Taratula O, Garbuzenko OB, Chen AM \& Minko T 2011a Innovative strategy for treatment of lung cancer: targeted nanotechnology-based inhalation co-delivery of anticancer drugs and siRNA. Journal of Drug Targeting 19 900-914. (https://doi.org/10.3109/10611 86X.2011.622404)

Taratula O, Garbuzenko O, Savla R, Wang YA, He H \& Minko T 2011b Multifunctional nanomedicine platform for cancer specific delivery of siRNA by superparamagnetic iron oxide nanoparticles-dendrimer complexes. Current Drug Delivery 8 59-69. (https://doi. org/10.2174/156720111793663642)
Taratula O, Kuzmov A, Shah M, Garbuzenko OB \& Minko T 2013a Nanostructured lipid carriers as multifunctional nanomedicine platform for pulmonary co-delivery of anticancer drugs and siRNA. Journal of Controlled Release 171 349-357. (https://doi.org/10.1016/j. jconrel.2013.04.018)

Taratula O, Dani RK, Schumann C, Xu H, Wang A, Song H, Dhagat P \& Taratula O 2013b Multifunctional nanomedicine platform for concurrent delivery of chemotherapeutic drugs and mild hyperthermia to ovarian cancer cells. International Journal of Pharmaceutics 458 169-180. (https://doi.org/10.1016/j. ijpharm.2013.09.032)

Taratula O, Patel M, Schumann C, Naleway MA, Pang AJ, He H \& Taratula O 2015 Phthalocyanine-loaded graphene nanoplatform for imaging-guided combinatorial phototherapy. International Journal of Nanomedicine 10 2347-2362. (https://doi.org/10.2147/IJN.S81097)

Thompson IR \& Kaiser UB 2014 GnRH pulse frequency-dependent differential regulation of LH and FSH gene expression. Molecular and Cellular Endocrinology 385 28-35. (https://doi.org/10.1016/j. mce.2013.09.012)

Torchilin VP 2010 Passive and active drug targeting: drug delivery to tumors as an example. Handbook of Experimental Pharmacology 197 3-53. (https://doi.org/10.1007/978-3-642-00477-3_1)

Tsutsumi M, Zhou W, Millar RP, Mellon PL, Roberts JL, Flanagan CA, Dong K, Gillo B \& Sealfon SC 1992 Cloning and functional expression of a mouse gonadotropin-releasing hormone receptor. Molecular Endocrinology 6 1163-1169. (https://doi.org/10.1210/mend.6.7.1324422) van Straten D, Mashayekhi V, de Bruijn HS, Oliveira S \& Robinson DJ 2017 Oncologic photodynamic therapy: basic principles, current clinical status and future directions. Cancers 9 19. (https://doi.org/10.3390/ cancers9020019)

Varamini P, Rafiee A, Giddam AK, Mansfeld FM, Steyn F \& Toth I 2017 Development of new gonadotropin-releasing hormone-modified dendrimer platforms with direct antiproliferative and gonadotropin releasing activity. Journal of Medicinal Chemistry 60 8309-8320. (https://doi.org/10.1021/acs.jmedchem.6b01771)

Varshosaz J, Hassanzadeh F, Aliabadi HS, Khoraskani FR, Mirian M \& Behdadfar B 2016 Targeted delivery of doxorubicin to breast cancer cells by magnetic LHRH chitosan bioconjugated nanoparticles. International Journal of Biological Macromolecules 93 1192-1205. (https://doi.org/10.1016/j.ijbiomac.2016.07.025)

von Alten J, Fister S, Schulz H, Viereck V, Frosch KH, Emons G \& Gründker C $2006 \mathrm{GnRH}$ analogs reduce invasiveness of human breast cancer cells. Breast Cancer Research and Treatment 100 13-21. (https:// doi.org/10.1007/s10549-006-9222-z)

Wang Z, Yu Y, Dai W, Lu J, Cui J, Wu H, Yuan L, Zhang H, Wang X, Wang J, et al. 2012 The use of a tumor metastasis targeting peptide to deliver doxorubicin-containing liposomes to highly metastatic cancer. Biomaterials 33 8451-8460. (https://doi.org/10.1016/j. biomaterials.2012.08.031)

Wang R, Hu X, Yue J, Zhang W, Cai L, Xie Z, Huang Y \& Jing X 2013 Luteinizing-hormone-releasing-hormone-containing biodegradable polymer micelles for enhanced intracellular drug delivery. Journal of Materials Chemistry: B 1 293-301. (https://doi.org/10.1039/c2tb00072e)

Wen D, Chitkara D, Wu H, Danquah M, Patil R, Miller DD \& Mahato RI 2014 LHRH-conjugated micelles for targeted delivery of antiandrogen to treat advanced prostate cancer. Pharmaceutical Research $\mathbf{3 1}$ 2784-2795. (https://doi.org/10.1007/s11095-014-1375-6)

Westphalen S, Kotulla G, Kaiser F, Krauss W, Werning G, Elsasser HP, Nagy A, Schulz KD, Grundker C, Schally AV, et al. 2000 Receptor mediated antiproliferative effects of the cytotoxic LHRH agonist AN-152 in human ovarian and endometrial cancer cell lines. International Journal of Oncology 17 1063-1069.

Xu C, Yuan Z, Kohler N, Kim J, Chung MA \& Sun S 2009 FePt nanoparticles as an fe reservoir for controlled fe release and tumor inhibition. Journal of the American Chemical Society 131 15346-15351. (https://doi.org/10.1021/ja905938a) https://erc.bioscientifica.com

https://doi.org/10.1530/ERC-20-0442 (c) 2021 Society for Endocrinology Published by Bioscientifica Ltd. Printed in Great Britain 
Xu P, Chen J, Chen Z, Zhou S, Hu P, Chen X \& Huang M 2012 Receptortargeting phthalocyanine photosensitizer for improving antitumor photocytotoxicity. PLOS ONE 7 e37051. (https://doi.org/10.1371/ journal.pone.0037051)

Yang T, Li F, Zhang H, Fan L, Qiao Y, Tan G, Zhang H \& Wu H 2014 Multifunctional $\mathrm{pH}$-sensitive micelles for tumor-specific uptake and cellular delivery. Polymer Chemistry 6 1373-1382. (https://doi. org/10.1039/C4PY01403K)

Yang-Feng TL, Seeburg PH \& Francke U 1986 Human luteinizing hormone-releasing hormone gene (LHRH) is located on short arm of chromosome 8 (region 8 p11.2 $\rightarrow$ p21). Somatic
Cell and Molecular Genetics 12 95-100. (https://doi.org/10.1007/ BF01560732)

Yates C, Sharp S, Jones J, Topps D, Coleman M, Aneja R, Jaynes J \& Turner T 2011 LHRH-conjugated lytic peptides directly target prostate cancer cells. Biochemical Pharmacology 81 104-110. (https://doi. org/10.1016/j.bcp.2010.09.015)

Zhang L, Ren Y, Wang Y, He Y, Feng W \& Song C 2018 Pharmacokinetics, distribution and anti-tumor efficacy of liposomal mitoxantrone modified with a luteinizing hormone-releasing hormone receptorspecific peptide. International Journal of Nanomedicine 13 1097-1105. (https://doi.org/10.2147/IJN.S150512)

Received in final form 21 June 2021

Accepted 6 July 2021

Accepted Manuscript published online 6 July 2021 (c) 2021 Society for Endocrinology Published by Bioscientifica Ltd Printed in Great Britain 